\title{
PRIVATE MONOPOLY AND THE PUBLIC INTEREST: \\ AN ECONOMIC ANALYSIS OF THE CABLE TELEVISION FRANCHISE
}

\author{
Thomas W. HAZLETT ${ }^{\dagger}$
}

Table of Contents

I. Legal Decisions ...................... 1336

II. MONOPOlY: NATURAL AND OtHERWISE .......... 1340

A. The Murky Concept of "Natural Monopoly" ... 1340

B. Does the Existence of Natural Monopoly Make a Sufficient Economic Case for Monopoly Licensing? 1346

1. The Costs of "Ruinous" Competition ...... 1351

2. An Example of Healthy Competition in a Declining Unit Cost Industry ........... 1355

3. The Costs of Municipal Regulation....... 1357

C. Is Cable Television a Natural Monopoly? ...... 1364

D. Natural Monopoly Versus Implicit Competition. 1375

III. Gompetttion: To Attract Consumers or to SeCURE THE FRANCHISE?.................. 1381

A. Political Competition and Consumer Welfare ... 1381

B. Actual and Potential Competition in an Open Market for Cable Television .............. 1387

G. The Obvious and Hidden Costs of Political RentCreation............................. 1400

Conclusion $\ldots \ldots \ldots \ldots \ldots \ldots \ldots \ldots \ldots \ldots \ldots$

With the rights of local governments to create cable television franchise monopolies being challenged widely on both freedom of the press and antitrust grounds, interest has focused largely on the issue of "natural monopoly." Cities argue that the prevailing cost conditions in the cable television industry make unfettered competition impractical at

$\dagger$ Assistant Professor, Department of Agricultural Economics, University of California, Davis. B.A. 1975, California State University, Northridge; Ph.D. (economics) 1984, University of California, Los Angeles. Giannini Foundation Paper, No. 812.

The author wishes to thank warmly Robert Bramson, William Lee, John Mansell, and Mark Nadel for alert criticisms and suggestions on an earlier draft, and Myung Whan Kim and Lynn Evans for highly competent research assistance. This is not meant to relieve the author of sole liability for his remarks. 
best and disruptive at worst. Following this rationale, many municipalities have issued de facto exclusive franchises to cable operators by exercising their right to determine the use of such public rights of way as utility poles and underground conduits. Yet, when challenged by potential cable suppliers arguing that governments have no right to erect monopolistic barriers in the form of municipal franchises, the defenders of cable television franchise monopolies often find themselves unable to make a convincing economic case for the existence of a natural monopoly, or given that case, to connect that argument to their public policy conclusion that net consumer benefits flow from monopolistic cable franchising. Using microeconomic analysis and existing empirical research, this Article sets forth a critique of the franchising authority of local governments over cable television.

\section{Legal Decisions}

Local government's franchising authority over cable television is currently the subject of intense litigation. As one leading legal analyst in the industry commented, "During any given month, it's hard to tell whether cable operators or local regulators have the upper hand in the topsy-turvy world of cable TV franchising litigation." " Since Community Communications Co. v. City of Boulder, ${ }^{2}$ which established that municipalities are shielded from antitrust liability only when they have received and acted pursuant to a clear and direct mandate to regulate from their respective state governments, ${ }^{3}$ municipal franchising authority has been challenged on both first amendment and antitrust grounds.

In Preferred Communications, Inc. v. City of Los Angeles, ${ }^{4}$ a potential supplier of cable television services sued the city of Los Angeles, alleging violations of the first amendment and the Sherman Act because the city refused to allow multiple entrants into the cable market. ${ }^{\circ}$ While the district court dismissed the complaint for failure to state a claim upon which relief could be granted, the Ninth Circuit ruled that plaintiff had stated a claim under the first amendment and remanded

I Mansell, PCI Prompts Cable Ops to Take Action, Cable TV L. ReP., May 28, 1985 , at 1.

2455 U.S. 40 (1982).

s See id. at 54 (citing City of Lafayette v. Louisiana Power \& Light Co., 435 U.S. 389, 413 (1978)); see also Town of Hallie v. City of Eau Claire, 105 S. Ct. 1713, 1719-21 (1985) (stating that the state action exemption shields a municipality's anticompetitive activities from federal antitrust laws even if the activities are only authorized, not compelled, and even if the conduct is not actively supervised by the state).

754 F.2d 1396 (9th Cir. 1985), affd, 106 S. Ct. 2034 (1986).

See 106 S. Ct. at 2035. 
for further proceedings. ${ }^{6}$ On further appeal the Supreme Court also found a colorable first amendment claim $^{7}$ although the Court declined "to express any more detailed views on the proper resolution of the First Amendment question ... without a fuller development of the disputed issues in the case."

The Ninth Circuit opinion in Preferred Communications recognized the impact of certain competitive market issues on the first amendment claim. Writing for the unanimous three judge panel in Preferred, Judge Sneed noted that if competition is physically feasible, a government's monopolistic franchising poses an "impermissible risk" of censorship and control. ${ }^{\circ}$ In deciding that plaintiff PCI's right to operate without a franchise was protected under the first amendment, the court stated:

We cannot accept the City's contention that, because the available space on such facilities [as utility poles] is to an undetermined extent physically limited, the First Amendment standards applicable to the regulation of broadcasting permit it to restrict access and allow only a single cable provider....

Moreover, PGI has alleged in its complaint that there is space available on the City's poles and in its conduits. PCI has alleged that the City has held itself out as a provider of space on its utility poles to cable television companies and that state law requires private utilities to make space available for the attachment of television cable. . . B Because we must accept these allegations as true, we must find that the physical scarcity that could justify increased regulation of cable operations does not exist in this case. ${ }^{10}$

Judge Sneed cast the cable television business in the mold of an electronic publisher enjoying constitutional protections. ${ }^{11}$ In this context, regulation through franchising is an impermissible function for local government because "[a]llowing a procedure such as the City's would be akin to allowing the government discretion to grant a permit for the operation of newspaper vending machines located on public streets only to the newspaper that the government believes 'best' serves

- See id.

7 See id. at 2037.

8 Id. at 2038.

- See 754 F.2d at 1409.

10 Id. at 1404 (citation omitted).

II Id. at 1409. 
the community, a practice we find clearly invalid."12

In an effort to retain the right to issue exclusive cable franchises, certain municipalities have constructed a natural monopoly defense of such franchises. ${ }^{13}$ These municipalities have been encouraged by Judge Posner's opinion in Omega Satellite Products Co. v. City of Indianapolis, ${ }^{14}$ which directed the lower court to consider economic findings concerning natural monopoly in adjudicating the legality of a cable franchise. ${ }^{15}$ The National League of Cities, the chief lobbying agency for municipal franchisers, claims as its first defense that "a cable operator is almost always a monopoly provider of cable services for the area covered by the franchise." ${ }^{16}$ As Michael J. Henderson finds:

Cities are increasingly characterizing cable television as a "natural monopoly".... [M]any have advanced the phrase "natural monopoly" as a justification for stringent controls over the cable television medium . . . . Some cablecasters share the view that the natural monopoly concept permits a municipality to grant the right to provide cable television services to only one company-at least so long as they are the ones who have been granted the right to enter the market. ${ }^{17}$

Despite the unsettled state of natural monopoly theory, ${ }^{18}$ its importance in the disposition of cases involving the cable television industry is illustrated by two recent decisions. In Berkshire Cablevision $v$. Burke, ${ }^{19}$ a bidder for a cable franchise sued the state of Rhode Island,

12 Id. (citation omitted).

13 William Sharkey defines natural monopoly as a condition that obtains "in a particular market if and only if a single firm can produce the desired output at lower cost than any combination of two or more firms." W. SHARKEY, THE THEORY OF NATURAL MoNopoly 54 (1982).

14 694 F.2d 119 (7th Cir. 1982).

15 See id. at 127.

${ }^{16}$ Cable Television Industry: Hearings Before the Subcomm. on SBA and SBIC Authority, Minority Enterprise and General Small Business Problems of the House Comm. on Small Business, 97th Cong., 1st Sess. 4 (1981) (statement of Seattle mayor Charles Royer, appearing on behalf of the National League of Cities).

17 Henderson, Municipal Ownership of Cable Television: Some Issues and Problems, 3 Comm./EnT. L.J. 667, 675 (1981) (footnotes omitted); see also Lee, Cable Franchising and the First Amendment, 36 VAND. L. REv. 867, 872 (1983) ("The assumption that cable is a natural monopoly permeates the franchising and refranchising process in most communities."); Note, The Evolution of Cable Television Regulation: A Proposal for the Future, 21 URB. L. ANN. 179, 185 (1981) ("Governments often refuse to grant franchise privileges to all cable applicants realizing that, consistent with natural monopoly theory, allowing many companies to commence construction would be inefficient....").

${ }^{18}$ See infra notes $28-54$ and accompanying text.

19571 F. Supp. 976 (D.R.I. 1983), vacated, 773 F.2d 382 (1st Cir. 1985). 
alleging that state regulations mandating that cable systems provide public access and other services effectively abridged the bidder's constitutional rights to free speech and just compensation. In deciding against the bidder Judge Pettine wrote:

The award of a franchise serves as a rational way of choosing which cable operator will provide cable television service within a particular service area. Cable operators often compete for a cable franchise but very rarely develop competing cable systems for the same service area. Such a franchising system recognizes the economic realities of the cable industry, which, as a practical matter, create a "natural monopoly" for the first cable operator to construct a cable system in a given service area. ${ }^{20}$

This view of the cable industry contrasts with that expressed by the court in Community Communications Co. v. City of Boulder. ${ }^{21}$ An existing cable operator in Boulder, Colorado sued the local government on antitrust and freedom of expression grounds after the city ordered it to curtail its expansion while the city began a franchising search for new entrants into the cable market. ${ }^{22}$ Noting the irrevocable injury to the plaintiff's business that could occur prior to resolution of the controversy, the district court granted plaintiff's request for a preliminary injunction against Boulder, thereby allowing plaintiff to build freely. ${ }^{23}$ On the natural monopoly question, Judge Matsch wrote:

I disagree that the evidence shows that cable television is such a natural monopoly that the only feasible competition is in the process of currying favor with the City Council to obtain a permit to operate. To the contrary, the evidence is that there can be competition in the marketplace, with the choice of price and service left to the consumers. ${ }^{24}$

The Tenth Circuit reversed the lower court opinion ${ }^{25}$ and was in turn reversed by the Supreme Court. ${ }^{28}$ In his Tenth Circuit dissent, Judge Markey endorsed Judge Matsch's resolution of the natural mo-

${ }^{20}$ Id. at $985-86$.

21485 F. Supp. 1035 (D. Colo.), rev'd, 630 F.2d 704 (10th Cir. 1980), rev'd, 455 U.S. 40 (1982).

22 See id. at 1037 . The plaintiff accused the city and one potential competitor of conspiring to replace the plaintiff with that competitor by revoking the plaintiff's legal right to operate. See id. at 1038.

23 See id. at 1040 .

24 Id. at $1039-40$.

${ }^{25} 630$ F.2d 704 (10th Cir. 1980).

26455 U.S. 40 (1982). 
nopoly question:

The city's sole argument in this case is that because there can be only one cable operator in Boulder, the moratorium was necessary to prevent [the plaintiff] from "wiring the entire city" before the city could conduct its bid process and select what it considered the "best" company to enjoy that monopoly. Not to put too fine a point on it, that argument is today simply fallacious. As the trial judge found, and as the record makes clear, modern technology makes free and open competition both practically and economically available to the city by at least four competing cable communicators. ${ }^{27}$

Clearly, the economic issues in local franchising and regulation of cable television are both important and unresolved. Perhaps most important are the issues surrounding the concept of natural monopoly. How is this economic concept defined? How does it apply to the cable television market? Is the policy of monopolistic franchising an optimal, or even a second best, solution to a natural monopoly problem? These issues comprise the focus of Part II, which explores competitive forces in both political and economic markets in evaluating the consumer welfare consequences of monopolistic licensing. The conclusion drawn is that the power of local governments to bar entry of potential competitors into the cable television market creates serious inefficiencies and cannot now be advanced convincingly as a proconsumer solution to a private market failure.

\section{Monopoly: Natural AND OTHERwise}

\section{A. The Murky Concept of "Natural Monopoly"}

While natural monopoly ${ }^{28}$ theory is today in a state of flux, economists have essentially agreed that economies of scale are neither necessary nor sufficient to explain the efficiency associated with a natural monopoly. ${ }^{29}$ In contrast, nearly a century ago, the existence of econo-

${ }^{27} 630$ F.2d at 712 (Markey, C.J., dissenting) (footnotes omitted). The majority differed with Judge Markey on a point of law but did not dispute or otherwise comment upon his economic analysis.

20 While natural monopoly may be neatly defined as a market served more efficiently by one firm than by two or more, see supra note 13 , this definition begs the question of market definition, which is crucial. Under this definition, either any surviving firm is a natural monopolist (using a narrow market definition) or none is (using a broad market definition). Issues of market definition are addressed in T. Hazlett, Three Essays on Monopoly 165-74 (1984) (unpublished Ph.D. dissertation, University of California, Los Angeles).

${ }^{29}$ See W. ShaRkEY, supra note 13, at 17; Hazlett, The Curious Evolution of 
mies of scale was established by some theorists as the sine qua non of natural monopoly. ${ }^{\text {so }}$ While such economies are sometimes still cited by regulators to justify certain public utility and other regulatory arrangements, the economics literature no longer recognizes such economies as logically necessitating the existence of a monopoly. "What favors a monopoly status for a public utility is not the mere fact that, up to a certain point of size, it operates under conditions of decreasing unit cost-an attribute of every business, including a farm or a hand laundry." 31 At the same time, "a natural monopoly can and often does exist under increasing cost conditions." "32

Dissatisfaction with the old "economies of scale equal monopolistic distortions" view was advanced most incisively by Harold Demsetz. ${ }^{\text {s3 }}$ In arguing that the existence of only one or a few firms in a market revealed nothing about the actual or potential competitive forces at work, Demsetz observed "that the asserted relationship between market concentration and competition cannot be derived from existing theoretical considerations and that it is based largely on an incorrect understanding of the concept of competition or rivalry."

The problem with an economies of scale justification can be seen in the following example. Suppose that a particular community has a demand for pets such that only one pet store may be operated profitably. Does this pet store "monopoly" inevitably imply an anticonsumer result, therefore creating an appropriate situation for government regulation? So long as entry and exit are free, or low-cost substitutes to the retail pet store are available, the free market monopoly is thought to be harmless. If the pet store charges prices significantly in excess of costs, or refuses to supply services that consumers find valuable-that is, which are worth more than their cost-competitive entry into the pet store market in this community would be encouraged. The possibility of competition or substitution will tend to keep monopoly suppliers honest and innovative; indeed, economists would predict that a legally enforced entry barrier, for example, an exclusive pet store franchise, would

Natural Monopoly Theory, in UNNATURAL Monopolies 1, 15-16 (R. Poole ed. 1985).

${ }^{30}$ See, e.g., W. Sharkey, supra note 13, at 15-16 (citing as an example the nineteenth-century scholar Henry Carter Adams, who "simplifie[d] the definition of natural monopoly to the purely technical condition of scale economies in the industry"). 32 J. Bonbright, Principles of Public Utility Rates 12 (1961).

32 B. Mitnick, The Polrtical Economy of Regulation 297 (1980). Even industries with increasing per unit cost may be naturally monopolistic under this analysis of one firm can serve the given market more cheaply than two or more, a condition known as "subadditivity."

ss See Demsetz, Why Regulate Utilities?, 11 J.L. \& EcoN. 55 (1968).

st Id. at 55 . 
cause prices to increase by diminishing the threat of entry by competitors. Accordingly, a one-firm market may be necessary for the existence of a monopoly problem, but is far from sufficient. Monopoly is not, strictly speaking, a numbers game. Consequently, defenders of regulation in the economics literature have shifted their focus to problems involving long-term investments in specific capital, theoretically an altogether different issue with distinct implications for regulatory policy. ${ }^{35}$

The current view of economists on the natural monopoly question is reflected in the "contestability" theory. Under this theory, a market may exhibit large fixed costs and important economies of scale and still be contestable, meaning that no tendency towards monopolistic output restriction is evidenced in open market competition. ${ }^{36} \mathrm{~A}$ contestable market must have either low barriers to entry or low barriers to exit. ${ }^{37}$ Competition in the airline industry presents classic examples of contestable markets. To send a Boeing 747 from Los Angeles to New York involves a high fixed cost and virtually no marginal cost, since the incremental cost of serving an additional passenger is minimal as long as empty seats remain on the plane. As a result, average cost declines sharply to the point of full capacity. Yet the high fixed costs that produce this situation are not sunk. Because the jet may be easily rerouted to fly from Los Angeles to Honolulu, for example, barriers to exit and, hence, to competitive entry, are considered to be low. That is, even if a firm must spend a considerable sum to lease or purchase a 747 , entry into any particular market is inexpensive because airplanes can be salvaged, and vacant seats refilled, without significant additional costs to an airline. ${ }^{38}$

The factor on which the existence of natural monopoly most depends, then, is not economies of scale or high fixed costs but capital salvageability. Where economies of scale dictate one supplier in a market, competitive forces will suppress prices to the level of costs as long as capital is still free to enter and exit. Moreover, free entry increases productive efficiency by disciplining contestants to innovate and to lower costs, thereby creating benefits for consumers, as is most poign-

3s See Goldberg, Regulation and Administered Contracts, 7 BeLL J. ECON. 426 (1976); Williamson, Franchise Bidding for Natural Monopolies-In General and With Respect to CATV, 7 BELl J. EcON. 73 (1976). Goldberg, for example, writes, "The 'justification' of regulation is seen to rest not on narrow natural monopoly (declining long-run average costs) grounds; rather it rests on the long-term relational matters stressed here." Goldberg, supra, at 445.

so See W. Baumol, J. Panzar \& R. Willig, Contestable Markets and THE THEORY OF INDUSTRY STRUCTURE 170 (1982).

s7 See id. at 5-7.

ss See id. 
antly demonstrated in the post-deregulation airline markets. ${ }^{39}$ Even if the number of suppliers in a particular market does not increase following deregulation, competitive forces more effectively constrain suppliers to act in the consumers' interests.

The case for regulation of public utilities and cable television franchises must now rest on the contestability, or capital salvageability, definition of monopoly. The mere fact that so much monopoly regulation has taken place in such certifiably contestable markets as the airline, trucking, long-distance telephone transmission, broadcasting, refuse collection, and taxicab markets, leads economists to suspect that the purpose of much monopoly regulation in America may be not to control monopoly, but to create it. ${ }^{40}$ Given the ease with which favored economic interests in the cable market can reward and hence influence political franchisers via campaign contributions, editorial influence, grants of cash or in-kind services to friendly constituencies, private stock offerings, postretirement employment, and so forth, it is incumbent upon those arguing for the creation of legal monopolies to establish that such franchises would not add to the long list of state-created monopolies serving very private interests.

In Preferred Communications, Inc. $v$. City of Los Angeles, ${ }^{41}$ the

30 See S. Morrison \& C. Winston, The Economic Effects of Airline DeREGULATION 1-3 (1986) (stating that deregulation as of 1983 had led to "at least a $\$ 6$ billion (in 1977 dollars) annual improvement in the welfare of travelers" and "to at least a $\$ 2.5$ billion (in 1977 dollars) annual increase in industry profits"). For a brief summary of the findings of Morrison and Winston's Brookings Institution study, see Passell, Flights of Non-Fancy, N.Y. Times, Apr. 28, 1986, at A24, cols. 1, 3 (editorial) (citing the study, which showed that despite minor disadvantages (e.g., an average $5 \%$ rise in travel time and an increase in fares on lightly traveled routes), deregulation had generated benefits worth about $\$ 87$ per round trip, and concluding, "Airline deregulation isn't merely a success, it's a triumph of capitalism and common sense that benefits practically everyone"); Hamilton, Benefits Seen in Airline Deregulation, Wash. Post, Apr. 16, 1986, at G1, col. 6 (citing the study, which showed that airline deregulation had resulted in benefits to travelers-one-third in lower fares, two-thirds in more frequent flights).

10 See Peltzman, Toward a More General Theory of Regulation, 19 J.L. \& ECON. 211, 231 (1976) ("[The rational regulator] will seek a structure of costs and benefits that maximizes political returns."); Stigler, The Theory of Economic Regulation, 2 Bell J. Econ. \& MGMT. ScI. 3, 5 (1971); Stigler \& Friedland, What Can Regulators Regulate? The Case of Electricity, 5 J.L. \& EcoN. 1, 1 (1962); Wilson, The Politics of Regulation, in The Politics of Regulation 357 (J. Wilson ed. 1980). Even where the existence of natural monopoly is relatively undisputed, as in electricity distribution, an interesting literature has arisen to question the emergence of proconsumer regulation. See, e.g., Jarrell, The Demand for State Regulation of the Electric Utility Industry, 21 J.L. \& EcoN. 269, 276-77 (1978). Jarrell found that state regulation of electricity rates came first to those states with the lowest electricity prices (adjusted for cost and demand factors) and that these newly regulated rates quickly rose relative to unregulated states' rates. Id. at 293.

11754 F.2d 1396, 1404 (9th Cir. 1985), aff'd, 106 S. Ct. 2034 (1986). "The City asserts . . . that, because cable television is a natural monopoly, economic scarcity justi- 
legal importance of going beyond the economies of scale argument was firmly established by the Ninth Circuit. Citing Miami Herald Publishing Co. v. Tornillo, ${ }^{42}$ the court wrote:

[The Supreme Court in Tornillo] refused to accept the plaintiff's argument that because economic conditions made entry into newspaper markets difficult, the government could impose a limited right of access to the press. Although the Court acknowledged that most newspapers enjoy a monopoly in their areas of distribution, it did not conclude that this circumstance gave rise to a duty to provide public access to the press. $^{43}$

The approximately 5000 municipalities ${ }^{44}$ that have issued de facto monopoly cable franchises must pin their hopes on a very liberal reading of Preferred Communications' logic concerning proregulation precedent: "Several cases, however, have concluded that cable's alleged natural monopoly characteristics do provide a basis for some degree of government regulation."45 These cases include Community Communications Co. v. City of Boulder, ${ }^{48}$ Berkshire Cablevision v. Burke, ${ }^{47}$ Omega Satellite Products v. City of Indianapolis, ${ }^{48}$ and Hopkinsville Cable TV v. Pennroyal Cablevision. ${ }^{40}$ The basis for allowing regulation of cable, as opposed to following the laissez faire rule embraced in Tornillo with respect to newspapers, is that in Tornillo "the characteristic of economic scarcity was unrelated to a disruptive use of the public domain requiring a government license," must significantly impact the public domain in order to operate; without a license, it cannot engage in cable broadcasting to disseminate information."

It is essential to define with care the public disruption rationale

fies government regulation ... . Id. at 1404 .

${ }^{42} 418$ U.S. 241 (1974).

43 Preferred, 754 F.2d at 1404-05 (citations omitted).

4t This figure is adduced by multiplying the ratio of franchised to unfranchised systems, as obtained from a Pennsylvania study, multiplied by the number of current cable systems nationwide, approximately 7000. Kahn, How Safe is Cable's "Natural Monopoly," Cablevision, Oct. 13, 1986, at 60, 61. See Noam, Economies of Scale in Cable Television: A Multiproduct Analysis, in Video Media Competition 93, 93 (E. Noam ed. 1985).

45 Preferred, 754 F.2d at 1405 (citations omitted).

4660 F.2d 1370, 1379 (10th Cir. 1981), cert. dismissed, 456 U.S. 1001 (1982).

47571 F. Supp. 976, 985-86 (D.R.I 1983), vacated, 773 F.2d 382 (1st Cir. 1985).

48694 F.2d 119, 127-28 (7th Cir. 1982).

48 562 F. Supp. 543, 547 (W.D. Ky. 1982).

so Community Communications, 660 F.2d at 1379.

51 Id. This language is cited by the Ninth Circuit in Preferred, 754 F.2d at 1405. 
that Judge Sneed finds in these cases, because it is altogether distinct from the natural monopoly problem. ${ }^{62}$ Inconvenience on public streets and limitations on rights of way may be caused by competitive or monopoly suppliers and may be eliminated in either a competitive or monopolistic environment. ${ }^{53}$ Yet the cities appear to rely on the public disruption rationale in alleging that natural monopoly necessitates government franchising of cable. ${ }^{54}$ broad.

${ }^{32}$ Judge Sneed quickly notes that the Community Communications standard is too

It suggests that simply because cable's disruption of the public domain gives rise to a need for licensing, it would also justify the monopoly the City seeks to create by its auction process. We find it necessary, however, to undertake a more detailed inquiry into whether the City's auction process is a permissible governmental response to the burden imposed by cable on public resources.

Preferred, 754 F.2d at 1405 (footnote omitted). He concludes that the city's auction process is not permissible. See id. at 1405-07.

There is every reason to believe that cities and cable regulators fundamentally understand that the line between the government's interest in protecting public property and the government's interest in regulating firms that use such property is a tenuous one. The oft-noted increasing complexity of such regulation is evidence of this. A recent paper on the subject of professional municipal cable regulators stated:

From its humble origins of exercising police powers over the use of municipal streets and rights-of-way, local regulatory control of cable has been extended to such areas as rate regulation, consumer protection, governmental utilization of broadband telecommunications capacity, and enforcement of compliance with the entire range of public services offered in the heat of the franchising competition.

B. Orton \& C. Griffin, Municipal Telecommunications Officers: A Profession Matures (speech delivered at the Annual Conference of the National Association of Telecommunications Officers and Advisors, St. Louis, Mo., Sept. 29-Oct. 2, 1985).

ss As Harold Demsetz has written:

Note clearly: scale economies in serving a market are not at issue. To see this, imagine that electrical distribution systems are thin lines of a special conducting paint. The placing of such systems causes no difficulties. They are sprayed over either public or private property. Nonetheless, suppose that the use of each system is subject to scale economies. Glearly, the desire to regulate cannot now be justified by such problems as traffic disruption, even though scale economies are present. "Excess" duplication is a problem of externalities and not of scale economies.

Demsetz, supra note 33, at 63. Fees, fines, or antidisruption regulations may be imposed impartially upon all comers whose activities engender public costs. Such impartial impositions would discourage negative externalities imposed by monopolists as well as by competitors.

Bs In a recent brief, the city and county of Sacramento claimed that their right to issue a monopoly franchise was not proscribed by the first amendment, partly on the grounds that "[t]he installation of even a single cable television system is accompanied by traffic congestion, an increased likelihood of accidents, and decreased access to emergency vehicles such as ambulances, fire trucks, and police cars." Appellee's Brief at 47, Pacific West Cable Co. v. City of Sacramento, 798 F.2d 353 (9th Gir. 1986). The brief contradicts itself, however, when it correctly notes that "even a single cable television" installation may cause problems. Id. It may be more difficult for local administrators to 


\section{B. Does the Existence of Natural Monopoly Make a Sufficient Economic Case for Monopoly Licensing?}

The central curiosity in the argument that cost conditions of natural monopoly mandate a public franchising for cable television is demonstrated in this syllogism: (a) the market will sustain only one cable supplier, hence (b) the local government must restrict the market to one cable supplier. From a public policy perspective, the extraordinary aspect of this logic is the manner in which it loops the first and last elements of a traditional four-part argument for monopolistic franchising without addressing the crucial issues.

The general rationale alleged for restrictive municipal licensing is as follows:

(1) There exist "subadditive" cost conditions; that is, one supplier has lower average costs than two or more identical firms serving the same market with the same product, presumably making monopoly inevitable or "natural";

(2) To prevent the monopolist from charging exorbitant prices, a franchise will be issued in exchange for the supplier's submission to some form of public regulation of product quality and price;

(3) This franchise monopoly will be reliably regulated by well-informed, efficient, and responsible civic officials and will give consumers lower effective prices than would exist in the absence of regulation;

(4) Therefore, the government should, as a matter of policy, issue monopoly franchises.

By skipping from an economic allegation of natural monopoly to a policy conclusion endorsing a monopolistic franchise, the syllogism simply states the nonsensical proposition that governmental power should be used to guarantee what is already guaranteed by market forces. Typically, cities do not as a matter of course address the efficiency of their regulatory scheme because they do not even regulate consumer prices for cable television. Cities generally have had only the ability to deny proposed rate hikes in basic cable service. ${ }^{\text {ss }}$ And because cities

supervise and regulate public disruptions caused by two or more firms, but the inconvenience of regulators is an exceptionally weak argument for the abridgment of the right to freedom of the press. Furthermore, it is a distinctively new and curious twist to the old natural monopoly argument.

so Robert Entman finds that "[l]ocalities that attempt rate-base of return regulation are rare. Most simply require cable companies to get official approval before posting a rate increase. . . . Relatively few cities have the time, personnel and expertise for 
have not been able to regulate the services offered, effective price regulation is rendered moot. Moreover, since 1979, cities have lacked any authority over premium channel prices; ${ }^{.6}$ as of December 29, 1986, they will have, generally, no power over basic cable rates, pursuant to the Cable Communications Policy Act of $1984 .{ }^{57}$ Thus, the traditional efficiency argument for regulation, whatever its empirical weaknesses, fails on its own terms. There is hardly even a pretense of price regulation "in exchange for" the monopoly franchise.

sophisticated rate analysis." R. Entman, Ain't Misbehavin'? Cable Television Franchising and the Case for Local Deregulation 13 (unpublished paper presented to the Fifth Annual Urban Affairs Conference of the University of North Carolina, Sept. 28-30, 1983). For instance, during the February-March 1985 period, 284 applications for basic cable rate increases were filed with local regulatory agencies nationwide. Of these, 1 was withdrawn and only 11 were denied. Of the 272 rate increases granted, only 5 were for less than the full amount of the requested increase. In other words, $94 \%$ of the proposed rate hikes were granted in full, suggesting a rather perfunctory aspect of the local regulatory process. See Paul Kagan and Associates, InC., Gable TV Rate INCREASES, Feb./Mar. 1985 (newsletter). Franchise regulators, however, may yet depress basic cable rates by either constraining the rate requests to less than profit-maximizing levels or by delaying rate increases.

o6 See Brookhaven Cable TV Inc. v. Kelly, 428 F. Supp. 1216, 1221 (N.D.N.Y. 1977) (upholding FCC deregulation of pay cable rates), affd, 573 F.2d 765 (2d Cir. 1978), cert. denied, 441 U.S. 904 (1979).

67 The Act states, "Any Federal agency or State may not regulate the rates for the provision of cable service except to the extent provided under this section." Cable Communications Policy Act of 1984, § 623(a), 47 U.S.C. § 543(a) (Supp. III 1985). The statute further provides that any state law limiting or preempting regulation of rates is to remain in effect only for two years from the effective date of congressional legislation, i.e., for two years from December 29, 1984. See 47 U.S.C. § 543(g) (Supp. III 1985). Furthermore, deregulation is to occur wherever the Federal Communications Commission finds "effective competition." See infra notes 186-87 and accompanying text for a discussion of effective competition.

s8 Victor P. Goldberg, in a modern defense of monopolistic franchising, described a government regulator as a proconsumer agent seeking a long-term arrangement with a natural monopolist in order to protect customers from monopolists' abuse of their heightened bargaining power. See Goldberg, supra note 35, at 439-44. Control over rates is, however, inherently part of the exclusive franchise deal. To Goldberg, the only real question is whether the service rates are determined initially or are regulated in a "flexible" fashion over time. He argues that in complex, long-lasting exchange relationships "the parties might find it much simpler and more economical to tailor a "flexible pricing' rule to their needs." Goldberg, Toward an Expanded Economic Theory of Contract, $10 \mathrm{~J}$. Econ. Issues 45, 50 (1976). Goldberg notes that in monopoly franchising the regulatory agent "must ... determine an initial rate structure and rules for adjusting the structure over time." Goldberg, supra note 35, at 439 . Consumers will find it in their interests to have agents regulate franchise monopolies in order to protect their right to be served at regulated prices: "[T] he customer . . . would like some protection for his reasonable price expectations against the good faith decisions of the supplier to terminate or to increase prices." Id. at 440 (footnote omitted)

Nowhere is it suggested that franchising should saddle consumers with monopoly pricing. Hence, the continuing legacy of the regulation-for-a-monopoly bargain is somewhat mysterious. Even after it was clear that regulation of leased access and pay services was impossible at the local level, a Booz Allen study recommended municipal regulation in the following terms: "Single franchise awards accompanied by appropri- 
It may be useful here to contrast this analysis of the traditional efficiency argument with that set forth by Judge Posner in Omega Satellite. ${ }^{\text {So }} \mathrm{His}$ informed and informative treatment of the natural monopoly issue will be quoted at some length:

The cost of the cable grid appears to be the biggest cost of a cable television system and to be largely invariant to the number of subscribers the system has. We said earlier that once the grid is in place-once every major street has a cable running above or below it that can be hooked up to the individual residences along the street-the cost of adding another subscriber probably is small. If so, the average cost of cable television would be minimized by having a single company in any given geographical area; for if there is more than one company and therefore more than one grid, the cost of each grid will be spread over a smaller number of subscribers, and the average cost per subscriber, and hence price, will be higher.

If the foregoing accurately describes conditions in Indianapolis-again a question on which the record of the preliminary injunction proceeding is sketchy at best-it describes what economists call a natural monopoly, wherein the benefits, and indeed the very possibility, of competition are limited. You can start with a competitive free-forall-different cable television systems frantically building out their grids and signing up subscribers in an effort to bring down their average costs faster than their rivals-but eventually there will be only a single company, because until a company serves the whole market it will have an incentive to keep expanding in order to lower its average costs. In the interim there may be wasteful duplication of facilities. This duplication may lead not only to higher prices to cable television subscribers, at least in the short run, but also to higher costs to other users of the public ways, who must compete

ate regulation produce uniform services to subscribers at reasonable cost . . . Subscriber rates and service levels are coming under increasingly stringent monitoring and control." Booz Allen, Analysis of Overlapping Franchises, Overbuilding, and Dividing Urban Markets in the CATV Industry for Cable Atlanta, Inc. and Georgia Cablevision Corp. IV-19 (Oct. 9, 1979) (unpublished report) (capitalization omitted). Although the study's predictions were poor (regulation of rates and of services has virtually disappeared, see supra notes 55-57 and accompanying text), there has been no great change in the views or arguments of the franchising advocates, thus suggesting a lack of seriousness in the economic case advanced by profranchising interests.

so Omega Satellite, 694 F.2d 119 (7th Cir. 1982). 
with the cable television companies for access to them. An alternative procedure is to pick the most efficient competitor at the outset, give him a monopoly, and extract from him in exchange a commitment to provide reasonable service at reasonable rates. ${ }^{60}$

This, in elongated form, is three-quarters of the four-part argument presented above, ${ }^{61}$ as adapted to cable. Logical requirements, however, still remain unsatisfied-as Judge Posner points out clearly within his Omega Satellite opinion (and elsewhere). The finding of economies of scale is necessary but clearly insufficient to establish the case for monopoly licensing by governments. Posner rounds out the analysis as he notes that the plaintiff petitioning for open cable competition "may be able to prove that the City officials were not acting in the consumer interest, that cable television in Indianapolis is not a natural monopoly, that exclusive franchising is a needlessly restrictive way of dealing with natural monopoly ...."92

Elsewhere Posner has been quite specific about the consumer problems inherent in publicly let franchise monopoly. In his important article Natural Monopoly and Its Regulation, ${ }^{63}$ Posner challenges the traditional rationale for government regulation of natural monopoly:

Much criticized in the details of its application, regulation is assumed by nearly all who work or write in the field, as by the public in general, to be fundamentally inevitable, wise, and necessary. However, personal experience as a government lawyer involved in regulatory matters made me skeptical about the validity of the assumption and this study has convinced me that in fact public utility regulation is probably not a useful exertion of governmental powers; that its benefits cannot be shown to outweigh its costs; and that even in markets where efficiency dictates monopoly we might do better to allow natural economic forces to determine business conduct and performance subject only to the constraints of antitrust policy. ${ }^{\text {s4 }}$

${ }^{60}$ Id. at 126. The idea that duplication of facilities may lead to higher short-run prices to subscribers is incorrect analytically because only marginal costs help to determine price, not historic or "sunk" costs. See infra note 73.

-1 See supra text following note 54 .

-2 Omega Satellite, 694 F.2d at 127.

os Posner, Natural Monopoly and its Regulation, 21 StAN. L. REv. 548 (1969).

- Id. at 549. Of course, scholarly opinion concerning the appropriateness of regulation has changed somewhat dramatically since Posner wrote this essay in 1969, in part because of this important article and Posner's subsequent work on the question. 
Posner concludes, "The benefits of regulation are dubious, not only because the evils of natural monopoly are exaggerated but also because the effectiveness of regulation in controlling them is highly questionable." ${ }^{\text {"8s }}$ But more important than his conclusion, for the purposes of this Article, is Posner's premise: that regulation of alleged natural monopoly is not justified merely by the presence of economies of scale. In challenging an idea so firmly lodged in the minds of regulatory personnel in 1969, Posner's critique revealed that the economies of scale argument simply assumed the need for regulation. Upon examination, the case against natural monopoly was not, also, a case for regulation. Posner's analysis of the natural monopoly issue soon led him to reject the "regulation is efficient" hypothesis in examining the monopolistic franchising of cable television:

At the municipal level, where cable regulation has usually taken the form of conditioning permission to use public rights of way upon the franchisee's agreement to rebate a portion of his gross revenues and provide free service to the city, the thrust of cable regulation has not been to limit monopoly profits, but, much more dubiously, to divert a portion of those profits to the public purse. We must inquire whether the present character of municipal regulation of cable television is accidental and easily remediable, or the result of more or less inherent conditions of local government. I suspect the latter is the case. ${ }^{86}$

Clearly, the existence of economies of scale is an insufficient basis for regulation on economic efficiency grounds. Yet, in legislative hearings and court testimony, municipalities equate proving the need for regulation with proving the existence of natural monopoly. ${ }^{67}$ The recent explosion of academic interest in the consumer welfare aspects of regulation provides a measure of the considerable range of issues entirely overlooked by the economies of scale defense of regulation. ${ }^{68}$

Accordingly even where the natural monopoly case is convincingly made, it alone is an inadequate criterion upon which to base the

65 Id. at 635 .

66 Posner, The Appropriate Scope of Regulation in the Cable Television Industry, 3 BELL J. ECON. \& MGMT. ScI. 98, 123 (1972).

67 Mark S. Nadel presents the standard rationale: "[B]ecause cable distribution exhibits characteristics of a natural monopoly, the locality usually awards only a single franchise for each area." Nadel, COMCAR: A Marketplace Cable Television Franchise Structure, 20 HARV. J. ON LEGIs. 541, 545-46 (1983) (footnotes omitted).

B For a collection of essays addressing some of these issues, see UNNATURAL MoNOPOLIES, supra note 29. 
franchise monopoly case. It must first be demonstrated that the public franchising authority is in a better position to realize the benefits of monopoly organization than the private marketplace, and that the political authorities know which private monopoly should receive the franchise. As the economies of scale argument assumes no difference between firms, there is, of course, no choice to make. The real world, however, offers no such comforting simplicity.

\section{The Costs of "Ruinous" Competition}

The notion that free competition will invite wasteful overinvestment with ruinous results and dog-eat-dog price wars is an old canard invoked by economists seeking to justify municipal monopoly franchising already in place. ${ }^{69}$ Two unanswered questions are posed by the logic of this notion: (1) why do private investors need to be protected from financial ruin? and (2) what, conversely, is the magnitude of the wasteful competition that political auctions bring forth?

To argue that self-interested business persons, risking their own dollars and reputations, are less able to recognize ruinous competition than city council members who do not directly realize any profit or loss is a curious economic theory, indeed. The very idea of regulators trying to save an experienced cable competitor, much against its will, from a disastrous fate, is itself testimony to the level of incredulity this theory would garner among professional economists. The simpler and more direct point is that the policy of regulation, or monopoly franchising, has never been publicly advocated to save capitalists at the expense of consumers. The fact that many, if not most, of today's competitors in the personal computer market, for instance, will not survive the dec$\mathrm{ade}^{70}$ is a wholly insufficient basis for erecting governmental barriers to entry. The entrepreneur, it is thought, best knows how to evaluate risky ventures. Moreover, the consumer clearly benefits from competition between rival businesses to become one of the few or only market

See Hazlett, supra note 29 , at 2-11.

${ }^{70}$ See, e.g., Schrage, Computer Industry Slump is Broad, Deep, Wash. Post, June 30,1985 , at G1, col. 2, G2, col. 5 (citing as one factor causing the crisis in the computer industry the entry of many new companies, which has led to overbuilding and overcapacity. "Clearly, so many competing companies just can't survive. The pain of the industrywide shakeout . . . has afflicted all industry players as all the competition has compressed profit margins further."); Pollack, As a Computer Market Frays; Osborne Just One Symbol of Problem, N.Y. Times, Sept. 16, 1983, at D1, col. 3 (stating that crisis in personal computer market is due primarily to too many suppliers with similar products (there are an estimated 150 companies in the personal computer business) and to the increasing dominance of IBM, which entered the personal computer market in 1981). 
survivors. ${ }^{71}$ Competition inevitably involves duplication costs, ${ }^{72}$ but long years of observation have convinced economists that the benefits of allowing consumers to choose the winners, as opposed to allowing politicians or government planners to select the firms that they believe consumers would (or should) choose, are, generally speaking, greater than the costs of consumer choice.

In any event, it is not the purpose of public franchising to protect irrational investors to the detriment of consumers. Once overbuilding increases the available supply of services, it can only decrease the price of such services. ${ }^{73}$ Yet, in fact, regulators have decried rivalries between direct competitors leading to rate wars. The benefit to consumers in such wars is undeniable; ${ }^{74}$ critics can only point to the arguably shortrun nature of lower prices. The worst outcome for consumers, of course, is the elimination through competition of all but one survivor: just the result that municipal franchising agencies routinely seek to

21 Indeed, Judge Posner notes that antitrust law respects the right of rivals to compete for the market, "that is, competition to be the firm to enjoy a natural monopoly." Omega Satellite, 694 F.2d 119, 127 (7th Cir. 1982) (citation omitted). Similarly, in Union Leader Corp. v. Newspapers of New Engiand, Inc., 284 F.2d 582 (1st Cir. 1960), cert. denied, 365 U.S. 833 (1961), the circuit court noted that competition between newspapers competing for a natural monopoly might be good for the consuming public: "[W]e cannot say that it could not be in the public interest to have one newspaper rather than another. Where there is no identity of performance we will not say that the public does not have an interest in competition even though that competition be an elimination bout." Id. at 584 n.4. It is crucial to note that this open entry competition for the market is entirely distinct from a publicly held auction for the right to serve the market, in that firms compete directly for consumers' favor, not for the good will of local politicians. See Owen, Recent Developments in Cable Television Regulation, Regulatory Reform: Indus. Reg. Comm. Newsl., Dec. 1985, at 4 (published by the Industry Regulation Committee of the ABA Section of Antitrust Law) ("There is nothing inherent in th[e] definition of natural monopoly that would permit one to draw the conclusion that the competitive process should not be allowed to operate in the usual way to benefit consumers.").

${ }^{72}$ If there were no duplication costs involved in a rivalry between firms, the firms would not be competing directly in the same market-that is, they would not be actually competing. Hence, duplication is a definitional component of direct competition.

${ }^{78}$ Even Judge Posner errs in stating, "[W]asteful duplication of facilities . . . may lead . . . to higher prices to cable television subscribers, at least in the short run." Omega Satellite, 694 F.2d at 126. The error is the famous "sunk cost fallacy"; once resources have been committed to a market, only their marginal cost affects supply, and hence, price. If duplicate investment could raise prices then incumbent monopolists would not have to worry about overbuilds, and head-to-head competition would be the typical case. Proponents of municipal franchising, of course, argue that prices will not sustain the investments of two or more competitors, thus rejecting, if implicitly, this erroneous sunk-cost reasoning.

24 A study for the city of Denver found that "[o]ne of the notable advantages for consumers in an overbuild situation is that service rates are competitive and therefore likely to be relatively low." Touche Ross \& Co., Financial and Economic Analysis of the Cable Television Permit Policy of the City and County of Denver 28 (Jan. 20, 1984) (unpublished study). 
impose.

If the demand for cable services is sufficient to make their provision profitable, the assertion of economies of scale begs the monopoly franchise question: what imbues the public franchising authority with the prescience to select the one firm offering the optimal mix of services over all submarkets in the franchise area? If the government could employ accountants, analysts, planners, and other experts to predict effectively the economic results of competitive markets, there would be no need for private capital markets to decide where society's investments should be made. Private firms as well as the government must themselves rely on projections of uncertain futures. But private markets boast two primary means to protect consumers: first, entrepreneurs who fail to meet the demands of buyers efficiently (or to pay competitive wages and returns on capital) lose their resources; second, competing entrepreneurs with better ideas are free to enter and capture the market. In other words, a policy of free entry and exit obliges any survivor to improve the opportunities available to consumers and other economic agents. ${ }^{75}$

In its proregulation decision in Berkshire Cablevision, the district court maintained:

[G]overnment franchising of the cable television industry is virtually indispensible. For example, since constructing a cable television system requires use of the public streets or telephone poles, the government has a substantial interest in limiting the number of cable operators who build cable systems.

Of course, the flip side to government franchising is that it insulates cable operators from unnecessary competition. The award of a franchise serves as a rational way of choosing which cable operator will provide cable television service

${ }^{25}$ Economist Bruce $\mathrm{M}$. Owen concludes of the cable market:

The competitive process is an important guarantee that the particular firm that does end up as the monopolist is in fact the most efficient and responsive seller. There is a world of difference between the performance that one would expect of a monopolist that survived a competitive struggle to serve its customers and what one expects of a monopolist that is granted a franchise that frees it through state action of any fear of competition. . . . [T] here is nothing inevitable about the identity of the monopolist in an industry that is a natural monopoly. That is, in many industries most efficiently composed of a single firm, performance is improved if that firm is subject to being replaced by another as the franchisee in the event that its prices are too high or its performance inferior.

Owen, supra note 71 , at 4 . 
within a particular service area. ${ }^{76}$

This version of the wasteful duplication argument fails to recognize that unnecessary competition is in the eye of the beholder. Any owner of monopoly rights believes that competition to dissipate his economic rents is unnecessary; furthermore, the "rational way of choosing" a monopolist has instant appeal to those economic actors favored by the "rational" selection process. But the case for efficiency must rest on some general interest served thereby, and the profranchising view refuses to address, let alone establish, the existence of such an interest. In order to justify monopoly licensing, it is apparently sufficient to label competition for a cable system in an open, unfranchised market as unnecessary, without further elaboration of its consumer welfare consequences.

Most fundamentally, the subjective nature of the political choice is ignored. Asserting that regulators can arrive at a solution by picking the best supplier through a rational method obscures all the essential elements of the choice itself. Indeed, public franchising vests politicians with the incredibly complex task of foreseeing consumer demands and new technologies, and of evaluating alternative supplies, efficient production methods, and an infinity of abstruse data, while giving them no financial incentive to choose well. In addition, rival suppliers are barred from entering the market to fulfill unsatisfied demand should the politicians make the wrong choice. Moreover, the cable television market poses more difficult challenges for the regulator than do many other industries. Although federal regulation of interstate trucking and air travel, for instance, is now deemed a consumer welfare failure, ${ }^{77}$ at least those industries presented relatively well known and stable technologies, outputs, and demands. As noted in an essay concerning federal deregulation of cable television:

[T]he task of supplying reasonably accurate information about how many common-carrier truckers will at what prices be serving Grand Rapids, Michigan, as a result of deregulation is easy when compared to the task of predicting how many over-the-air and cable broadcast facilities will be located in Grand Rapids, supplying at prices to be predicted what character of programming to what fractions of the population from what local origination, network, syndicated, or distant-signal sources as a result of a yet-to-be specified sub-

${ }^{78}$ Berkshire Cablevision, 571 F. Supp. 976, 985-86 (D.R.I. 1983) (citations omitted) (emphasis added).

ग7 See infra note 125. 
set of deregulation proposals, using a technology that may well evolve in new directions as a consequence of whatever policy change is made. ${ }^{78}$

\section{An Example of Healthy Competition in a Declining Unit Cost Industry}

Analogies to the telephone, electric, gas, and water utility industries proffered by advocates of monopoly licensing in cable franchising gloss over important assumptions within a natural monopoly argument. Assertions that cable television possesses the high fixed (or sunk) cost and low variable cost attributes of other distributional natural monopolies do not adequately address serious competitive issues. For instance, with respect to the important firm homogeneity assumption embodied in the natural monopoly argument, distributional industries with high fixed costs often actually prosper, in the consumer welfare perspective, from a competitive open entry policy that allows differentiated firms with diminishing per unit costs to battle freely for consumers' dollars.

The overnight mail delivery market instantly springs to mind as an example of healthy competition in a declining unit cost industry. ${ }^{79}$ The vast, worldwide distribution service of an established incumbent should theoretically constitute an insurmountable barrier to all prospective entrants. ${ }^{80}$ All newcomers must undertake to duplicate all local offices, delivery routes, advertising and marketing efforts, and sorting facilities of the existing monopolist, while merely splitting the market's

78 Besen, Mitchell, Noll, Owen, Park \& Rosse, Economic Policy Research on Cable Television: Assessing the Costs and Benefits of Cable Deregulation, in Deregulation of Cable Television 45, 49 (P. MacAvoy ed. 1977) (footnote omitted).

70 Lest it be alleged that the post office analogy creates a straw man, let us note that franchising advocates have advanced the example themselves. In pleading for municipal control of cable, the city and county of Sacramento allege, "The obvious legal analogy is the post office or the telephone system, both of which are now regulated as common carriers." Appellees' Brief, supra note 54, at 42 . Curiously, both markets cited are ones in which alleged natural monopoly cost conditions have justified governmentally imposed entry barriers that are today seen as injurious to consumer welfare. For a discussion of the postal market, see infra notes 80-81 and accompanying text. The long distance telephone market is now seen as entirely contestable, although competitive microwave technologies, available since the 1940 's, have been stifled by promonopoly regulation. Importantly, such competition is now seen as feasible and proconsumer, despite large fixed investments that presumably dictate downward-sloping average cost curves in production.

80 Furthermore, any potential entrant may be assured that the incumbent will not exit: even if operating at a loss, the United States Postal Service would almost surely continue to operate through cross-subsidies or Treasury payments, as in past years. This makes entry riskier than where the incumbent is privately owned and thus more likely to exit a tight market. 
customers. An accounting study would clearly demonstrate that a monopolist could serve the entire overnight mail delivery market at a lower per unit cost than two or more firms (i.e., overbuilt competitors) of identical efficiency. Such a hypothetical study, of course, precisely mirrors the natural monopoly argument made by cable franchising authorities.

The fortune made by Federal Express and other competitors of the natural monopoly of the United States Postal Service powerfully attests to the tenuousness of the homogeneity presumption. Firms may be afforded profitable opportunities to compete in declining average cost industries where quality differences are important. ${ }^{81}$ Theoretically, it would still be better-that is, more efficient-for regulators to observe the shortcomings of an incumbent monopolist and to direct that monopolist's movement in the appropriate welfare-maximizing direction. Unfortunately, such observations are best made within the context of openly competitive markets, where actual market efficiencies are reliably recorded in profit and loss statements. Thus, the accounting study conclusions that fixed or sunk costs are high and that, as a result, a market is most cheaply served by one supplier, are wholly insufficient as premises upon which to prohibit competitive entry.

Most importantly, the postal example aids in understanding the dynamics of franchising by revealing the unpredictability of unregulated entry. While consumer selection has now proved the virtue of competitive entry, suppose that in 1975 a regulatory board was charged with deciding on a nationwide overnight postal franchise. Should it have imposed a monopoly franchise solution, selecting the best single supplier, or alternatively, adopted an open entry policy? The natural monopoly argument could certainly have been advanced; a monopoly franchise could have been promoted as the rational means of eliminating unnecessary competition. The regulator's quandary would have lain in discerning necessary from unnecessary competition ex ante. What means would have been available to divine the optimal market structure and number of firms, their desired product output, or their owner-

81 See, e.g., Apcar, For Post Office, Overnight Mail Service is Absolutely, Positively Not So Easy, Wall St. J., June 12, 1985, at 33, col. 3. While Federal Express commands at least $40 \%$ of overnight mail delivery market and the Post Office's Express Mail about 33\%, "a host of upstart carriers, sensing vulnerability in their governmentsponsored competitor, acknowledge they are targeting Express Mail customers to increase their own market share." Id. These competitors rely on differences between their services and the Post Office's to attract customers: the private services pick up (the Post Office does this only at an extra charge); the services can easily trace lost packages (the Post Office process can require ten days); the services promise delivery by the next morning (the Post Office, by 3 p.m.), and so forth. See id. at cols. 3-5. 
ship? The overnight mail delivery example provides a vivid demonstration of the advantages of allowing market competition to regulate entry, even in industries in which presumed cost conditions lead regulators to discount the potency of competing, "unnecessary" entrants.

\section{The Costs of Municipal Regulation}

Whatever the cost to discover the correct number, size, identity, inputs, outputs, production functions, and price schedules of cable television suppliers through market competition, any proper analysis of monopoly franchising must compare this cost to the alternative cost of political licensing. There is no cost-free alternative available. Public franchising via monopoly auction will not costlessly end wasteful competition but will simply shift such competition to a different set of market demanders. Competitors will repackage their products to court these new consumers. Enormously expensive franchising campaigns have plagued the cable industry, ${ }^{82}$ as have serious delays, political corruption, overpromising by cable companies, and postfranchise haggling over contract terms. ${ }^{88}$ Because the costs of awarding and regulating

${ }^{82}$ During the competition to obtain the 226,000 home franchise issued by the city of Denver in 1982, the New York Times reported:

So far, the [three] companies have spent nearly $\$ 1$ million apiece competing for the lucrative 15 -year contract and have waged intense advertising, lobbying and promotional campaigns aimed at winning the support of civic leaders, community organizations and minority groups.

All of the companies have pledged millions of dollars to support local programming and community-access channels, including providing as many as 26 fully equipped studios scattered through the city. Teleprompter has proposed to turn over 20 percent of the franchise to the city government, which would hold it as a charitable trust.

Schmidt, Millions Spent in Contest for 'Showcase' Denver Cable Contract, N.Y. Times, Feb. 22, 1982, at A12, cols. 2, 4. A study commissioned by the city soon after the award was made concluded that the franchisee had committed itself to supply double the channel capacity required to serve consumer demand fully, leading to an overinvestment costing roughly $\$ 8$ million. Touche Ross \& Co., supra note 74 , at 3941. Even a false start, when a city decides not to choose any franchisee, can be highly costly. In Philadelphia, which decided to begin its franchising process anew in 1984, "[f]inancial reports filed with the city show that the cable companies spent about $\$ 6$ million since August 1982 to prepare and promote the proposals that were rejected yesterday." Wolf, After Three False Starts, Cable Firms are Leery of Phila., Phila. Inquirer, Jan. 26, 1984, at 10-A, cols. 1, 3.

8s See Williamson, supra note 35 . In discussing the problem of franchise awards, Mark S. Nadel writes:

The principal difficulty with this procedure is that it requires political bodies to make highly subjective judgments based on ambiguous multiple standards. There is tremendous pressure on applicants to expend their resources on political maneuvering and to make unrealistic promises concerning rates and technical features. Resources also are normally allocated 
franchise monopolies are significant, the mere assertion that the free market cannot costlessly achieve an equilibrium is insufficient to establish a prima facie case for monopoly franchising.

The most problematic political cost of regulation springs from the incentive for public authorities to create durable monopolistic profit opportunities. The calculus is straightforward: where voters are rationally ignorant in the sense that it would cost them more to become intimately familiar with every detail of local government than their vote is likely to be worth to them; where municipal issues are many, and where terms of office-holders are staggered such that there is no single referendum on the cable television franchise decision (even one implicit within the platforms of candidates), then local politicians will have an incentive to make their cable franchise decision, at least in part, on the basis of special interest considerations. ${ }^{84}$ This leads the franchising au-

to public service offerings of the system, without any evaluation of whether the benefits derived from offering these services justify the costs.

Nadel, supra note 67, at 547 (footnotes omitted). Leading industry consultants have recently characterized the process as follows:

- "The competition was just like any other auction, and companies felt they had to outbid each other, at any cost, just to win the franchises....

Then, after the franchise was won, they started to worry about building what they had promised ... they tried to convince cities that the systems should be scaled back." (statement of Carl Pilnick)

- "It didn't matter if one company promised 16 [local origination] studios and another promised 17, both clearly in excess of what a city might need .... What mattered was winning." (statement of Howard Gan)

- "Cities tried to turn cable into a political football . . . to milk the industry for all it was worth. . . . Companies knew they were being pressured into unrealistic concessions, but they had to play along." (statement of Paul Kagan)

Getlin, Cable TV: A New Season of Austerity, L.A. Times, Jan. 5, 1985, at I-1, col. 1, 24 , col. 1. The writer notes, interestingly, that "[w]hile many local officials have insisted that companies honor their promises, virtually every cable firm seeking such changes has won concessions." Id.

os The screen between voters and the cable franchise decision is not easily penetrated. As a first step in closely monitoring politicians, voters would have to be fully informed as to all applicants responding to the city's "request for proposals" (RFP) in order to judge their representatives' proconsumer sentiment. In fact, great knowledge of all possible cable applicants and product mixes would be necessary for a well informed voter, because RFPs and the resultant applications are inherently biased toward the political concerns of incumbent representatives. This is an enormous information requirement. Gathering good information is very difficult even for the public officials who must vote on the franchise selection, because extensive research is required as to what could be supplied in the local cable market if the political authorities did not franchise cable at all. A state investigator describes the typical situation:

Few public servants, elected or appointed, have the time or background to understand fully what cable television will mean to their communities. Local government frequently calls in consultants to develop needs assessments and to evaluate the responses to the request for proposals for a cable sys- 
thorities, as rational, self-interested agents, to increase monopoly power via franchise agreements in order to create market value that they may reallocate in a political framework. Since these fattened franchises will be sought in public auction, the politician can expect to receive offers for the monopoly rights equal to the discounted present value of such rights. The bids will only partly be paid as cash payments to local government coffers; $^{85}$ they are also paid through campaign contributions, offers of free program time and use of production facilities to influential interest groups, advantageous equity offerings to political supporters of key legislators, and an overinvestment in nonremunerative cable services. ${ }^{86}$

The politicized nature of such decisions quickly dispels any illusions about concern for the general interests of consumers. Local lobbying ability dominates the "rational" selection of a monopolist, reducing the influence of general consumer interests on selection. In an accurate assessment of the cable franchising process, Donald Sizemore, a former

tem. . . . [I]t is not unusual for cable companies to be able to orient their proposals toward specific consultants whose evaluation systems have been studied. Thus, what looks good on paper may well bear no relationship to reality.

Sizemore, The New Politics of Cable Television, GAL. J., Aug. 1982, at 297, 298.

${ }_{85}$ The outright (lump sum) auction was rendered illegal by a ruling of the Federal Communications Commission. See 47 C.F.R. § 76.31(b) (1973). This limited the tax imposed by municipalities to $3 \%$ of franchisees' gross revenues per year, unless special conditions are shown, in which case taxes could be raised to a maximum of $5 \%$. This latter cap has now been codified by Congress. See Cable Communications Policy Act of $1984, \S 622(\mathrm{~b}), 47$ U.S.C. $\$ 542$ (b) (Supp. III 1985). The mere fact that it was deemed necessary to restrain cities from "overtaxation" is evidence of the anticonsumer sentiment inherent in municipal cable regulation.

${ }_{88}$ In contesting for desirable markets, cable companies approach each franchise very much the way a politician approaches an election, mapping a strategy, outlining the key issues, and recruiting influential supporters. One of the most widely used tactics is what is known in the industry as the "rent a civic leader" approach-a large cable company will invite a group of local citizens to help it form a local cable company. Local interests usually control 20 percent of the new enterprise. The large cable company keeps the rest and agrees to build the system if the franchise is awarded. Only one of the major cable companies, UA-Columbia Cablevision, has so far refused to take in local partners. President Robert Rosecrans says: "We don't believe in giving away 20 percent."

In Fort Wayne, Indiana, A.T.C.'s local partners included the organizers of an educational-TV station and a group of black ministers. Cox Cable, which is about to become a subsidiary of General Electric, allied itself with a local cable company that already had the franchise for the surrounding county. Cox Cable's partners apparently had more clout-it won. Henry Harris, the former president of Cox Cable and now head of Metrovision, a joint venture with Newhouse, thinks that "having the right local people is 80 percent of the game."

Bernstein, Television's Expanding World, ForTunE, July 2, 1979, at 64, 67. 
consultant to the California State Senate's government operations subcommittee, which investigated cable franchising, writes:

The lobbying process begins with the hiring of politically savvy and influential local consultants. These people are not chosen for their knowledge of cable television or community needs. Rather, they are experts on the local officials and the political arena. These consultants trade upon the special relationships they have established with the local authorities in order to gain improved access and credibility for their employers.

The next stage in lobbying is to line up support for a company's proposal among influential community groups. Such support is gained by tailoring parts of the franchise proposal to benefit the goals of these groups. Thus, one company might dedicate a portion of its revenue to the maintenance of a deficit-ridden art museum. . . .

Finally, there is the most controversial franchise-winning tactic of all-rent-a-citizen. Prominent local people are given stock in the subsidiary that will operate the franchise. These individuals are usually part of the local political scene and important to the continued political success of those who will grant the franchise. ${ }^{87}$

87 Sizemore, supra note 84 , at 297 . The following account of the auction for one of the major Los Angeles City franchises adds interesting detail to Sizemore's general franchising scenario. The process to award the East San Fernando Valley franchise began in 1978 but had not, by mid-1985, resulted in the wiring of the franchise area, although United Gable had received a franchise in 1983. In seeking the franchise award, six companies contributed over $\$ 300,000$ directly to political campaigns and undertook lobbying expenditures including the following:

- Assigning at least one and sometimes two or three high-powered lobbyists to each council member. The lobbyists include former California Attorney General Evelle Younger and former Supervisor Yvonne Brathwaite Burke.

- Recruiting community leaders as supporters by offering them company stock, usually at low rates. These so-called "rent-a-citizens" could make huge profits if their firm wins and they later sell their stock.

- Entertaining council members in posh restaurants, throwing gala receptions for the entire council and providing officials with Christmas gifts, tickets to plays and movies, private boxes at the racetrack and other favors.

- Offering money and television equipment to influential grass-roots groups in return for their endorsements.

Company spokesmen say that high-powered lobbying is a fact of life. "We have to do these things, to make these contributions. . . . It's just part of the process," said Joe Cerrell, a Group W consultant.

Getlin, Council Besieged by Cable TV Lobbyists, L.A. Times, Aug. 3, 1982, at I-1, col. 3 , I-3, col. 1 . The article also quotes industry analyst Carl Pilnick as saying, "Cable firms believe it's who you know that counts'. . . They seek out such people only for 
It may thus be in the interests of regulators to enhance monopoly power rather than to dissipate it, and in particular, to create lasting monopoly power that may be difficult for future voters to retract. ${ }^{88}$ This aspect of franchising, which is a real fixture of the political world, is not considered in arguments seeking to justify public regulation of alleged natural monopoly. Most importantly, it recognizes the influence of rational self-interest in the political realm. In contrast, the public interest view of natural monopoly regulation assumes away incentive and informational problems for government actors, but holds that private parties still contend with the grubby incentives and uncertainties of the real world. Hence, the conclusion that open competition is wasteful and that monopoly franchising is in the consumer's interest is derived not by analysis, but by asymmetric assumption. ${ }^{80}$

The disadvantages and perverse political incentives arising from franchise monopoly have led many economists who concede some or all of the natural monopoly argument with respect to cable television to question the advantages of regulation. Douglas Webbink summarizes the dilemma as follows:

[E]ven if CATV [community antennae television, i.e., cable television] is a natural monopoly, that is not sufficient evidence to show that common carrier or public utility regulation would be efficient. . . . [I]t would be necessary to show that consumers or society are better off if there is regulation of entry, exit, rate of return, specific rates, expenditures, and conditions of service, rather than if those were left

their influence, and they do this all over the nation." Id.; see also Boyarsky, Political Hired Guns Now Working for Cable Firms, L.A. Times, Dec. 5, 1981, at I-1, col. 1 (describing how cable companies employ former political campaign staff workers to promote cable bids through polls, parties, political contributions, and stock distributions).

${ }^{88}$ Robert J. Michaels makes this point quite clearly. The more likely a given monopoly right is to stay in place, the higher a price the politician can command for awarding that monopoly right in the present period. See Michaels, Long-Term Political Agreements and the Origins of Bureaucratic Power, in PuBdIC CHOICE IN NEW ORLEANS 37 (G. Tullock ed. 1978). This explanation may shed light on the reasons that monopoly cable franchises are issued for 15 to 20 years or more, when a 2 to 4 year construction period protection would be sufficient to eliminate any wasteful duplication problem and irresistably establish a "rationally" selected natural monopolist (assuming the cities' natural monopoly argument).

89 Interestingly, this methodological error mirrors the general theoretical treatment of monopoly in the economics literature. Harold Demsetz notes: "The oft-asserted inefficiency of monopoly is based on a comparison to the standard of perfect decentralization, a standard that is theoretically derivable only under the very conditions denied by the existence of a monopoly-caused deadweight loss." H. Demsetz, Economic, Legal, and Political Dimensions of Competition II-20 (Sept. 1981) (discussion paper 209, University of Galifornia, Los Angeles, Department of Economics). 
unregulated. ${ }^{90}$

Dr. Webbink also notes, "Assuming that CATV is currently a natural monopoly, that still does not imply that there is any reason to restrict entry," "91 suggesting that new technology is a progressive means of combatting monopoly. ${ }^{92}$ Webbink concludes, "[I]t might be desirable to place a flat ban on exclusive franchises, given the small probability that they are ever in the interest of consumers."

Bruce Owen and Peter Greenhalgh, in a widely cited work on cable television, are also very clear about the high costs of franchise monopoly. They estimate economies of density equal to about $14 \% .^{84}$ While some champions of franchising are tempted to advance such economies as evidence of the efficiency of franchise monopoly, ${ }^{85}$ Owen and Greenhalgh go in quite a different direction: "Although this is hardly negligible, it is within the range of monopoly markups that might be expected in the absence of competition or effective regulation. Therefore, consumers might be better off with competition, in spite of the cost penalty from lost scale economies." ${ }^{\text {"98 }}$ They conclude their study by stating:

Both the evidence and the policy considerations suggest that policymakers should at least seriously consider the benefits of an open entry policy [with respect to cable television franchising]. Economies of scale and cost subadditivity, while present, are not so substantial as to entirely rule out the possibility of effective actual or potential competition in this industry. ${ }^{97}$

The study's conclusion is all the more powerful when the cost of government regulation incurred during the process of granting franchises is factored into the equation. If an overbuild of identical sys-

on Webbink, Should Cable TV Be Regulated As a Public Utility?, 89 PuB. UTIL. ForT., June 22, 1972, at 32, 33-34.

${ }_{93} I d$. at 34.

${ }^{22}$ See id. This farsighted view of cable predates current advances in technology, which many local governments are attempting to keep from consumers. See infra text accompanying notes 152-55.

${ }^{93}$ Webbink, supra note 90 , at 34 .

or See Owen \& Greenhalgh, Competitive Considerations in Cable Television Franchising, 4 ConTEMP. POL'Y Issues 69, 76 (1986). This implies that two identical overbuilt systems would experience costs about $14 \%$ higher than one monopolist serving the same customers.

os See Nadel, supra note 67, at 541 n.1; Affidavit of Professor G. Richard Meadows at 3, RVS Cablevision Corp. v. City of Brookfield, No. 83-C-1686 (E.D. Wisc. March 11, 1985).

${ }_{98}$ Owen \& Greenhalgh, supra note 94 , at 76.

${ }^{97} I d$. at 78. 
tems, the worst-case scenario from a cost perspective, ${ }^{88}$ were to increase per unit costs by $14 \%$, these costs could plausibly be more than entirely offset by eliminating the costs of politically demanded services required of exclusive franchise winners but of low economic value to consumers. ${ }^{8 \theta}$ Indeed, empirical evidence suggests that just this sort of offset is likely. The firm of Ernst \& Whinney has found that for a typical franchise, "[a]pproximately 22 percent of total subscriber revenues are used to cover costs which the system would not have incurred without the franchise requirements. When the system is mature, this will amount to approximately $\$ 5.60$ per month per subscriber."100

It is just this sort of anticonsumer government intervention that leads economist $\mathrm{G}$. Kent Webb to question the wisdom of franchise monopoly. Webb believes that "[f]rom the perspective of cost, cable television is a natural geographic monopoly."101 Significantly, Webb does not argue that natural monopoly invariably warrants monopoly franchising. In the very same discussion, Webb addresses the broader question of public policy: "Neglected in this [natural monopoly] conclusion are the direct and indirect costs of regulation that may be incurred if the cable system is to operate as a monopoly."102 In Webb's view, whatever the industry cost function, political regulation is no panacea. As he observes in his concluding chapter, under the now obsolete assumption of local price regulation:

The case study of Philadelphia supports the premise that when several firms participate in the competitive bidding for a cable franchise, prices are proposed that can be expected to produce approximately normal profits for the

${ }^{88}$ This maximizes the duplication penalty. Were different systems to be overbuilt, as is more likely, enhanced consumer choice would tend to mitigate the duplication problem.

${ }^{29}$ If consumers valued the services highly (i.e., were willing to pay in excess of their marginal cost of provision), cable firms would eagerly supply and profit from them, making local governments' mandate of such services superfluous.

100 Ernst \& Whinney, The Cost of Cable Television Regulatory \& Franchise Requirements: A Preliminary Analysis 3 (Apr. 1982) (unpublished study prepared for the National Cable Television Association). In its analysis of the Denver franchise, the Cable Television Information Center (CTIC) gives a 16\% estimate, which differs from the Ernst \& Whinney estimate only in its far more optimistic assumption of an average monthly revenue per subscriber of $\$ 37.50$. In actual dollar terms, CTIC found costs to be $\$ 6.00$ per month per subscriber, compared to Ernst \& Whinney's estimate of $\$ 5.60$. See Touche Ross \& Co., supra note 74, at 41; table 2, infra p. 1397.

101 G. Webb, The Economics of Cable Television 59 (1983). With respect to this empirical conclusion, Eli Noam comments that Webb's "brief and simple estimation" yields economies of scale "so vast . . . as to be unpersuasive." Noam, supra note 44 , at 95 .

103 G. WEBB, supra note 101 , at 59. 
firm. Monopoly market power has not been eliminated, however; it is sometimes exercised indirectly by the municipality, which may require extensive investment in public facilities as one of the terms of the franchise contract. In doing so, the municipality uses the monopoly status of the cable system to extract revenue from households in the franchise area. ... .

Ironically, although much of the public concern regarding the abuse of monopoly market power has been directed at the private firm, it is often the municipalities, charged with regulating the industry, that have wielded the market power. ${ }^{103}$

\section{G. Is Cable Television a Natural Monopoly?}

Municipalities argue that because one cable firm can serve a given area more cheaply than two or more, cable television distribution is a natural monopoly. Accounting evidence from industry experts is commonly introduced to show that direct competition is either impossible, wasteful, or both.

This argument is suspect on at least three counts. First, it clearly confuses economies of scale with economies of density. ${ }^{104}$ That is, while hypothetical cost studies ${ }^{105}$ purport to show that two firms covering all of a city cannot operate as cheaply as one, such studies do not address the traditional economies of scale question. For instance, Touche Ross case studies in Maple Heights, Ohio; Denver, Colorado; and Jefferson City, Missouri "found that average costs would be substantially lower if one operator served the market than if two operators competed in an overbuild." 108 Even if two overbuilt firms are more expensive than one, the errant conclusion is that one large firm is less costly on a per unit basis than two (or $n$ ) firms each serving half (or $1 / n$ ) of the geographic market. Conceding that a cost advantage arises from spreading firms out spatially, such studies do not make a case for one large firm serving an entire franchise region.

The advantages to consumers of allowing several smaller firms to

103 Id. at $179-80$.

104 Strictly speaking, economies of density are a distinct type of economies of scale. Density economies are scale economies where volume is measured on a per mile or per number of homes passed basis rather than on an absolute size standard.

105 These studies do not use actual figures based on data from operating systems but projections of the cable companies competing for a franchise.

${ }_{106}$ Declaration of Jay C. Smith $\mathbb{2 9}$, at 14, Pacific West Cable Co. v. City of Sacramento, No. CIV S-83-1034 MLS (E.D. Cal. May 9, 1985). 
serve different parts of a city are apparent. ${ }^{107}$ The main point, however, is that density economies may coexist with diseconomies of scale. Monopoly franchises may well create wasteful monopoly conditions by extending franchise regions beyond efficient parameters. In an open entry environment, a single firm that overexpanded would be defeated by smaller, more efficient rivals. At bottom, economies of scale refer to system size, not density.

To claim that any given city or county can be run as one system more cheaply than as two or more nonoverlapping systems does require an economies of scale argument, but the economic analyses offer little support for such an argument. Eli Noam, in his study of 4800 cable systems, finds significant economies of scope, meaning that integrating cable provision and cable programming seems to be efficient, but "fairly small returns to scale are observed for the separate output measure 'Homes Passed,' which is largely a transmission definition of output."108 Similarly, Owen and Greenhalgh conclude that "cable service prices do not in fact vary substantially with city size."109 Even a profranchising study concluded from a survey of cable systems that "[n]o relationship has been reported between size of franchise area and various basic or additional services specified,"110 and that "[p]roposed subscriber rates have not been related to franchise areas."111

Second, the accounting methodology of typical cost studies encourages recommendations of one firm per region by assuming high fixed costs and constant variable costs. This methodology creates by definition

107 Fundamentally, the availability of several suppliers allows consumers to select successful competitors subjectively in an open market, rather than forcing them to rely on the political selection process, and preserves the option of direct rivalry as a constraint on monopolistic behavior. Alfred E. Kahn and Irwin M. Stelzer note:

If we were to encourage cable companies to operate, if not one on top of the other, then at least in adjacent territories, this would create the possibility that the performance of the one could always be held up as a model for the performance of the other; or that dissatisfied patrons of the one might, at least at the margin of their respective territories, invite the other in to take over the service. Competition even at the fringes of each territory could have a powerful demonstration and stimulative effect for the entire area.

A. Kahn \& I. Stelzer, Communications Regulatory Reform in New York State: A Report Prepared at the Request of Gov. Hugh L. Carey 5 (Mar. 25, 1981) (unpublished study prepared by the National Economic Research Associates, Inc.) (footnote omitted).

${ }_{108}$ Noam, supra note 44, at 113.

109 Owen \& Greenhalgh, supra note 94, at 77.

110 Booz Allen, supra note 58, at III-8.

111 Id. This may help to explain why large city cable systems are remarkably unprofitable. According to cable securities analyst Anthony Hoffman of A.G. Becker, "The city is a hostile cable environment that is filled with inefficiencies not found in rural areas or small towns." Cooney, Cable TV's Costly Trip to the Big Cities, ForTUNE, April 18, 1983, at 82. 
a situation of declining average cost, yet its constant variable cost premise is questionable. For instance, management appears to become more expensive on a per unit basis as output expands. As firms become larger they require more layers of supervision and control, the cost of which offsets in part, wholly, or more than wholly, declining per unit costs realized from spreading a fixed plant investment over an increasing number of subscribers. In practice, large cities such as Los Angeles and Philadelphia ${ }^{112}$ routinely subdivide their exclusive cable franchises into several nonoverlapping regions. ${ }^{113}$

In addition, because the headend investment is not a fixed cost in servicing a large metropolitan area, the diseconomy of scale problem associated with managing bigger and more complex systems becomes all the more important.

The frequent amplification required to maintain the strength of signals traveling through coaxial cable limits the extent to which the cost of the headend can be shared. Excessive amplification reduces signal quality to below acceptable levels. As a result, the largest market that can be adequately served by a single headend is about six miles in radius. ${ }^{114}$

Hence, the inevitable limitations on technical economies of scale, combined with managerial diseconomies of scale, may help to explain some striking empirical inconsistencies with the natural monopoly argument. For instance, if average cost declines significantly as homes passed or number of subscribers increases, then it appears reasonable to predict that the thirty largest cable systems in the United States, with an average of 95,913 subscribers each, ought to offer equivalent services at lower prices than the thirty-one smallest systems, which average just 186 subscribers. ${ }^{115}$ Yet 1982 data from Paul Kagan and Associates in-

112 As of June 1981, the city of Los Angeles had issued eight franchises and was planning to issue at least four more. None of these licenses involved overlapping jurisdictions. Five franchises each included 150,000 or more homes. City of Los Angeles Department of Transportation, Gable Television Statistics (June 1981) (unpublished study). In 1979, Philadelphia was divided into four cable franchise regions despite having but 400,000 homes citywide. See Booz Allen, supra note 58, at exhibit 1 .

113 The increasing per unit cost of managerial coordination is exceptionally difficult to discern from proposals put forth by managers who are in the process of attempting to convince public officials of their ability to run a franchise-wide monopoly efficiently.

114 See G. WEBB, supra note 101, at 153.

118 Data is drawn from Paul Kagan and Associates, The Kagan Gensus of Cable and PAY TV (Dec. 31, 1982), as analyzed in T. Hazlett, supra note 28, at 351-53. The 30 largest systems are compared with the 31 smallest systems because there was a tie for 30 th smallest. 
dicates that the average price charged by the smaller systems for basic cable is $5 \%$ below, and for premium channels is $9 \%$ below, the average price charged by the larger systems. ${ }^{116} \mathrm{By}$ contrast, it is difficult to imagine an electrical generation facility serving only 200 customers operating at a lower unit cost or charging lower prices than a facility serving 100,000 users. If economies of scale exist in the cable television industry, such economies are certainly so modest as to be far less in evidence than in traditional natural monopoly industries, and thus can be easily overcome by other factors. The existence of a simple, linear, and inverse relationship between per unit costs and output, suggested by the economies of scale argument, is not supported empirically.

In cable television, as in most industries, factors that lower per unit costs as scale increases are in tension with other factors that raise per unit costs. The interplay of these offsetting effects is highly complicated and depends on variables such as geography, capital market conditions, timing, managerial expertise, labor costs, consumer preferences, technology, and marketing costs. Without an objective standard by which to predict the most efficient level of production, and given the high level of complexity involved, the political entities awarding cable franchises have virtually no mechanism by which to discern the most efficient scale. For this reason, economists are presumptively sympathetic to market survivorship as an efficient selector of the optimal size of firms as opposed to arbitrarily imposed size constraints. As Donald McCloskey explains:

A firm that is "fit" in the size it has chosen will survive by being profitable. Unfit species will vanish. If sizes of firms in the retail women's clothing trade cluster around one size (of firm-or, for that matter, of dress), we seek reasons for the apparent optimality of the size. We use the results of selection to guide what would otherwise be an impossibly difficult inquiry into the cost curves of firms. If there were no presumption that the sizes and other characteristics of firms that survive are in fact the least cost characteristics, economic studies would be as crippled as would be ecological studies that could make no presumption that the cowardice of wolves in the hunt or the falling of leaves in autumn are in fact valuable for the survival of wolves or of broadleaf plants. ${ }^{112}$

116 These price differentials are statistically significant at the $95 \%$ level. See $T$. Hazlett, supra note 28 , at 352 .

${ }^{117}$ D. McCloskey, The Applied Theory of Price 265 (1982) (footnotes omitted). 
Third, the assumption that identical outputs are produced by hypothetically identical rivals in a competitive scenario intrinsically renders the outcome of the competition, whether sustainable or not, meaningless. A scenario in which two firms simultaneously offer consumers identical products at identical costs does not allow the advantages of competitive enterprise to be realized. The serious error in making this assumption is demonstrated by the realization that virtually all commercial and industrial firms in the economy exhibit the declining per unit cost attribute supposedly exhibited by cable television companies. As Martin L. Weitzman writes:

For a variety of reasons, including dynamic learning effects, modern mass-production methods tend to be characterized by economies of scale or average costs that decline as output is expanded over the long run. In most industries the cost per unit of output is less for a high-volume producer than for a low-volume producer. From automobiles to books to computers-and on through the product alphabet-every business person knows that unit costs typically go down with the size of the production run. ${ }^{118}$

Yet, both in this country and abroad, vigorous rivalry exists even in such declining-cost industries. There is competition because different firms offer consumers different packages:

Counteracting this tendency toward bigness is the fact that not all people want exactly the same thing . . . . You may like the peppiness of a Ford Mustang while I want the service reliability of a Toyota Corolla. A Maytag washing machine is initially more expensive to buy than a Whirlpool, but it saves on future energy and maintenance costs. The IBM computer is better for business uses, but the Digital is superior for scientific work. Such examples can be replicated almost indefinitely.

... The predisposition for declining costs to cause high-volume production is thus offset by constrained buyer interest. ${ }^{110}$

The argument that a given supplier can produce additional services more cheaply than an entering competitor may also be offered to bolster the natural monopoly analysis. Such cost advantages are gener(1984).

118 M. Weitzman, The Share Economy: Gonquering Stagflation 11 118 Id. at 11-12. 
ally labeled economies of scope and are to some degree extant in commercial and manufacturing businesses everywhere. It is theoretically cheaper for an established firm to serve specialized preferences than for an entrant to incur all the start-up costs already paid by the established firm. It is certainly much cheaper, for instance, for Ford Motor Company, which has already sunk billions of dollars in a massive nationwide marketing organization consisting of hundreds of dealerships, wholesalers, and advertisers, to market the Honda Civic, than it would be for a small motorcycle manufacturer with virtually none of Ford's sunk cost advantages, to do the same. Similarly, how do both the New York Daily News and New York Post stay in business head-to-head, when the fixed costs of reporters, printing presses, and advertising sales personnel so dwarf the variable cost of one more section or column ${ }^{120}$ Differences among firms are reflected in many tangible and intangible attributes, including reliability, timing, personnel practices, packaging, marketing skill, financial expertise, and servicing. Countless product parameters form a bewildering matrix of firm qualities, differentiating competitors to consumers even where rivals appear indistinguishable to the policy analyst or government regulator.

In short, by focusing exclusively on economies of scale and assuming away all differences between products and among consumer tastes, one loses altogether the very rationale for competitive enterprise. If each firm offers the same output, and each industry exhibits some decreasing unit costs, the obvious course is to have governments establish "efficient" state monopolies over all industries. Significantly, competition's greatest advantage lies in the efficient selection process it offers in instances where firms are many, their products diverse, entrepreneurial talents unpredictable, and consumer preferences difficult to discern. ${ }^{\mathbf{1 2 1}}$

${ }^{120}$ The current intense newspaper rivalry between the Detroit News and the Detroit Free Press, for example, shows the tension between scale economies, which tilt the market to monopoly, and heterogeneous consumer preferences, which invite multiple entry. See Vise, Detroit Newspaper Rivalry May End Soon, Wash. Post, Aug. 25, 1985, at F1, col. 3.

${ }_{121}$ Sowell describes the information-seeking propensities of market competition as a subtle process:

Economic knowledge need not be articulated to the consumer, but is conveyed-summarized-in the prices and qualities of goods. The consumer may have no idea at all-or even a wrong idea-as to why one product costs less and serves his purposes better; all he needs is that end-result itself. Someone must of course have the specific knowledge of how to achieve that result. What is crucial to economic competition is that better and more accurate knowledge on the part of the producer is a decisive competitive advantage, regardless of whether the consumer shares any part of that knowledge. In political competition, accurate knowledge has no such decisive competitive advantage, because what is being sold is not 
It should be noted carefully that all competition is wasteful duplication when viewed from the comfortable confines of the homogeneity assumption underlying the economies of scale argument.

The natural monopoly defense of the municipal cable television franchising industry rests its empirical case on the widespread existence of monopoly in the industry. ${ }^{122}$ This case is questionable; the existence of monopoly, whether in franchised jurisdictions or in open entry communities, is not by itself evidence contradicting the consumer advantages of free competition.

First, the creation of monopolies by governments may reflect a political, rather than an economic, efficiency. Hence, it may be that a legal, not a market, entry barrier promotes one-seller markets. Judge Posner clearly identifies government as the source of cable monopoly:

As the cable television business now operates, subscribers are rarely if ever given a choice between cable companies; only one cable company solicits their patronage. The immediate cause of this, however, is not any inherent characteristic of cable television but the fact that a cable company must obtain a municipal franchise in order to be permitted to serve any part of the community. Whether it is because they assume that the cable television business is a natural monopoly, and they desire to limit the (surely minor) inconvenience to the public of having several companies using public rights of way to string or lay cable, or alternatively, because they seek a share of monopoly profits in the form of franchise fees, municipalities do not grant more than one cable franchise in any area within their jurisdiction. ${ }^{123}$

Further, Posner discusses franchising of cable television companies assuming the presence of natural monopoly. cost conditions and concludes:

[T]here is a danger that the franchising authority will be

an end-result but a plausible belief about a complex process.

T. Sowell, KNowledge AND Decisions 38 (1980).

${ }^{122}$ Speaking for the U.S. Conference of Mayors in federal hearings, Thomas Taylor, mayor of Westland, Michigan, employed the natural monopoly argument to ask, "If cities cannot retain the right to regulate rates . . . who will protect the consumer of this monopolistic service from price gouging?" Crock, The Fight to Control Cable TV Franchises, Wall St. J., Sept. 18, 1981, at 30, cols. 4, 5. Similarly, National League of Cities' attorney Nicolas Miller has noted of cable systems: "They are monopolies created not by the cities, but by the marketplace. . . . The issue is whether they'll be regulated or unregulated monopolies." Cohen, Cable-Television Firms and Cities Haggle Over Franchises That Trail Expectations, Wall St. J., Dec. 28, 1983, at 34 , cols. 1,3 .

${ }^{123}$ Posner, supra note 66, at 111. 
tempted to offer applicants not merely the right to wire homes in its jurisdiction but the exclusive right to do so. By adding a legal monopoly to the franchisee's natural monopoly, the franchising authority may be able to extract a larger sum from the franchisee, but at considerable social cost; for the grant of long-term exclusive franchises to cable companies may retard the process by which changes in technology can, over time, erode a natural monopoly. ${ }^{124}$

Posner implies that at least some regulation occurs for political profit rather than for consumer welfare. Monopolistic regulatory arrangements have historically proven more lucrative to the regulatees and regulators than to the public. William $\mathrm{K}$. Jones is quite explicit with respect to the benefits of such arrangements:

The danger is that regulatory restrictions upon entry will be employed to bar entry into markets that lack natural-monopoly characteristics and in which competition would be beneficial. (Restrictions upon entry into trucking and air transportation are examples of misplaced entry controls; these markets do not exhibit natural-monopoly characteristics, and the regulatory programs in these industries lack any other discernible rational foundation. $)^{125}$

To evaluate monopoly franchises accurately, one must compare the verifiable benefits accruing to consumers of franchise monopolies with the benefits offered by firms operating in an open entry market in which actual and potential competitors are free to regulate the behavior of cable television suppliers. In a sample of twelve open entry systems, 1982 prices for basic and premium services did not differ significantly from national averages although these open entry systems consisted

124 Id. at 113.

125 Jones, Deregulation and Regulatory Reform in Natural-Monopoly Markets, in Deregulating American Industry 39, 48 (D. Martin \& W. Schwartz eds. 1977). Note that the airline industry is no longer believed to present a natural monopoly problem although it exhibits pronounced scale of economies and was alleged to be a natural monopoly by regulators for decades.

Just as airline deregulation is viewed as benefiting consumers, see supra note 39, so has deregulation in the trucking industry brought benefits to shippers. See, e.g., Machalaba, Shippers' Market: More Companies Push Freight Haulers to Get Better Rates, Service, Wall St. J., Dec. 18, 1985, at 1, col. 6 (While deregulation has resulted in failure of some trucking companies and in loss of some jobs, shippers have cut more than $\$ 25$ billion from freight costs, an estimated $\$ 10$ billion of which is reflected in lower prices for consumers, who now receive better on-time service and the advantages of specialized new equipment.). 
largely of low density communities. ${ }^{126}$ Dale City, Virginia, for example, charged only $\$ 5.50$ monthly for basic cable, a rate just $\$ .05$ above the lowest in the state. ${ }^{127}$ This system, with 7000 subscribers, had a penetration ratio (homes connected divided by homes passed) of $93.3 \%$, the sixth highest in Virginia. ${ }^{128}$ This ratio is significant in that a monopoly problem is thought to exist when a firm is able to restrict output from the competitive level, and thereby raise its prices. In signing up nearly nineteen of every twenty homes in its service area, the Dale City "unregulated monopolist" does not appear to be engaging in a great deal of monopolistic output restriction. ${ }^{129}$

In such open entry communities, where cable suppliers are required only to pay general business license fees and satisfy regulations governing private use of public rights of way, entry occurs easily but generally does not result in overbuilt systems. An absence of overbuilding does not render competition useless (or wasteful) because the legally credible threat of entry may effectively constrain the incumbent monopolist's behavior. Indeed, the most efficient competition would be that which gives resource owners the incentive to act in the consumers' interests, without, however, requiring the expenditure of real resources. Such competition, however, depends on an absence of legal barriers, so that firms are free to enter should the incumbent's behavior become sufficiently careless as to warrant direct competition. The dearth of overbuild situations in jurisdictions allowing open entry may be evidence of open entry's efficiency in constraining prices to competitive levels rather than proof of competition's impotence. ${ }^{\text {so }}$

126 See Hazlett, Competition us. Franchise Monopoly in Cable Television, 4 CoNTEMP. POL'Y IsSUES 80, 83-85 (1986).

127 See id. at 84.

128 See id.

120 Other examples of open entry jurisdictions are unincorporated Pima County, Arizona; San Diego County, California; and Prince William County, Virginia. See id. at 83-85.

${ }^{180}$ Because multiple cable entrants are legally barred in localities awarding exclusive franchises, the proportion of overbuilds is exceedingly difficult to discern in that no comprehensive listing of free entry jurisdictions is available. While nearly 100 multiple franchise awards have been identified historically, see table 1, infra p.1374, several hundred unfranchised systems may today be in existence nationally. For instance, a recent Pennsylvania cable survey found that 32 systems in the state operated without official franchise agreements. These systems represented $15.9 \%$ of the systems surveyed for which a definite franchise or no-franchise status could be determined. See D. Allen \& D. Kennedy, Municipal Regulation of Cable Television in the Commonwealth of Pennsylvania 3-11 (Dec. 1982) (unpublished paper, Pennsylvania State University: Institute of Public Administration). A casual survey of the evidence reveals that while overbuilding rarely occurs in open entry jurisdictions, it is fairly common in multiple franchise areas. See table 1, infra p. 1374. It may well be that the continued threat of potential entry is a more efficient regulator than multiple franchising. 
Direct competition can and does occur. Established systems in Chapman, Kansas; Niceville, Florida; and Colorado Springs, Colorado have very recently been challenged by direct competitive entry, although Niceville's entrant was a municipally owned cable firm. ${ }^{\mathbf{1 3 1}} \mathrm{In}$ deed, inviting competition may now be gaining favor as a regulatory device among communities: "[T]here are situations in which city officials, frustrated with the incumbent operator, will be attracted to overbuilds as a quick and easy means to increase the pressure to improve service."132 Direct competition between overlapping franchises has also been credited with increasing the construction rate as competitors pushed to wire homes before rivals in Phoenix, Arizona, and with lowering prices and improving service in an ongoing twenty-year overbuild in Allentown, Pennsylvania. ${ }^{138}$

For all the effort spent by cities, their consultants, and franchise monopolists to dispel the notion that direct competition is a viable market possibility, their own evidence suggests the "impossible." Because overbuilds are not legally feasible in the monopoly franchise jurisdictions that comprise the vast majority of cable distribution systems, ${ }^{134}$ the opportunities for multiple entry and overbuilding are severely limited. Yet using data from a promonopoly study commissioned by the city of Monroe, Georgia, and introduced as an exhibit in other franchise litigation, we can discern that of ninety-three multiple cable 21-22.

131 See Moozakis, Range Wars, Cable Television Bus., Sept. 15, 1985, at 21,

132 Id. at 23 .

1s3 See Promised Land?, Cable Television Bus., Sept. 15, 1985 at 22-23. Other analysts have noted, "In many cases, municipalities have elected to award multiple competitive cable franchises in the belief that competition would accelerate saturation (homes passed as a percentage of total homes in the franchise area), and this has often been the result. . . . A wiring race between competitors in Paramus, New Jersey (7,700 households) resulted in construction of cable facilities [in] over 95 percent of the city in only 20 months . . . " Pearce, Peterson \& Fredrickson, Competitive Cable Franchising: Analysis of Economic Theory and Empirical Data 15 (1982) (unpublished study for the city of Monroe, Ga.) [hereinafter Pearce]. "In years past, a handful of municipalities with undeveloped systems permitted overbuilding to stimulate construction speed and to generate municipal franchise fees. . . . Intense wiring races culminating in significant overbuilding, caused saturation levels in Allentown, Bryan, Salisbury, and Warrensburg to approach 100 percent." Booz Allen, supra note 58, at IV17 (emphasis and capitalization omitted).

${ }_{134}$ Even in the pro forma arrangement under which a municipal government issues a "nonexclusive" franchise, it customarily issues only one such franchise. Although nominally nonexclusive, it is a de facto exclusive franchise. Even if it were theoretically possible to obtain a duplicative franchise, the legal costs involved would form a significant barrier to entry, the size of which may be discerned from the considerable legal fees cities are themselves willing to incur to fight for their right to issue sole nonexclusive franchises. Even overlapping franchise awards may introduce a monopoly problem by facilitating tacit collusion between franchisees and deterring more efficient firms from entering. 
systems franchised by local governments by mid-1982, fifty-one exhibited varying degrees of direct competition. ${ }^{135}$ Moreover, at least thirteen additional localities entertained such competition for some period, and twenty-two of the most recently franchised areas had not yet been wired. ${ }^{136}$ Hence, it appears safe to say that, where overbuilds are permitted by local authorities, they are an important source of actual as well as potential competitive pressure. ${ }^{137}$

Table 1

\begin{tabular}{lcccc}
\hline Time Period & $\begin{array}{c}\text { Multiple } \\
\text { Franchise } \\
\text { Awards }\end{array}$ & $\begin{array}{c}\text { Entry } \\
\text { Has } \\
\text { Occurred }\end{array}$ & $\begin{array}{c}\text { Continuing } \\
\text { Overbuilds } \\
\text { (as of 1982) }\end{array}$ & $\begin{array}{c}\text { Consolidated } \\
\text { Overbuilds }\end{array}$ \\
\hline Pre-1978 & 24 & 24 & 4 & 13 \\
1978-1982 & 69 & 47 & $22-47^{\mathrm{a}}$ & N/A \\
TOTAL & 93 & 71 & $26-51$ & 13 \\
\hline
\end{tabular}

Source: Pearce, Peterson \& Fredrickson, Competitive Cable Franchising: Analysis of Economic Theory and Empirical Data 12-14 (1982) (unpublished study for the city of Monroe, Ga.).

as"Twenty-two of these are extensive and continuing overbuilds. Twenty-five are partial overbuilds or overlapping franchises under construction ...." Id. at 12.

Of further importance is this study's conclusion that " $[\mathrm{t}]$ he marked increase [1978-82] in the number of multiple franchises now available can be traced to changes in the cable TV marketplace and the range of services now available."138 The increase in available services provides another way of introducing the firm heterogeneity objection to the pro forma natural monopoly analysis, since the objection strengthens as product differentiation increases. ${ }^{139}$ In the past, large cable suppliers, or multiple systems operators (MSOs), were reluctant to overbuild "when more attractive alternatives [were] available," such as tapping virgin markets on an uncabled continent. 140 "Now such alternatives are increasingly scarce."141 Moreover:

In recent years, growth in the availability and accep-

1ss See table 1, infra p. 1374.

136 See id.

${ }^{137}$ As table 1 indicates, overbuilds occurred in between $37 \%(26 / 71)$ and $90 \%$ $(64 / 71)$ of the cabled jurisdictions in the Pearce study that issued multiple overlapping franchises. See id.

${ }^{138}$ Pearce, supra note 133, at 14.

1s9 It is also worth noting that, as pay services come to form an increasing proportion of the cable package, the fixed cost component of plant investment fades in relative importance.

160 Pearce, supra note 133, at 14.

141 Id. 
tance of pay TV has increased internal cash flow and enhanced operators' ability to secure the external financing necessary to support the development of overbuilt franchises. The diversity of programming available has strained the capacity of some older systems to deliver all the services that their subscribers would like to receive. For these reasons and, in some cases, because of deteriorating service quality from existing franchisees, many more municipalities than before are inviting bids from multiple franchises, and more well-financed operators are responding. ${ }^{142}$

The implication that "older systems" are disadvantaged by technological advance is itself an attack on the economies of scale argument for monopoly franchises. If an incumbent supplier enjoys significant cost advantages over all outside competitors, and all firms are assumed to be identical in their management expertise, production efficiencies, and proconsumer attitudes, the incumbent will easily be able to purchase all the new products, capacity, or technology needed in order to preclude effective competition. The empirical fact that some old systems were pressured, rivaled, and even defeated in the cable marketplace is direct evidence, on the one hand, of the inapplicability of the natural monopoly assumptions, and, on the other hand, of the progressive attributes of open competition in forcing proconsumer innovation.

\section{Natural Monopoly Versus Implicit Competition}

Overbuilds often spark a period of intense competition ending in a consolidation. This result, however, does not negate the importance of competition through overbuilding, which performs at least two critical proconsumer functions. First, consumers benefit as better services and lower prices are offered in exchange for their patronage. Rivalry gives firms strong incentives to make favorable offers and allows a discovery period that reliably rewards behavior pleasing to consumers with enhanced market share. The rivalry stage may be long-lived. For example, two Bryan and College Station, Texas, cable firms competed directly from 1971 until 1984, when they were purchased and consolidated by a third firm. ${ }^{143}$ Moreover, while the competitors featured twenty-seven and thirty-five channel systems, ${ }^{144}$ their basic rates were the lowest in the state as of 1982 , each charging only $\$ 4.00$

142 Id.

14s See Touche Ross \& Co., supra note 74, at 25.

14 See id. 
monthly despite a Texas average of $\$ 8.50 .0^{145}$ Furthermore, because proponents of monopoly licensing claim that mergers of cable systems are smoothly achieved and "the problems associated with overbuilding diminish rapidly,"146 competition appears to create large proconsumer returns at very modest risk.

Second, should competition through overbuilding indeed prove uneconomic in some instances, its mere possibility serves to regulate monopolists in all jurisdictions that fail to erect protectionist franchise barriers. The argument that inviting entry is an expensive proposition has two dimensions: the new cable entrant will surely think twice about sinking new capital, but an established incumbent will also think twice about giving potential competitors cause to raid its market. In a technologically progressive industry such as cable television, an operating monopolist may well be nervous about more modern suppliers, as the state-of-the-art is superseded every five years or so. If the unnecessary competition argument is grounded empirically in the unprofitability of duopoly, the incumbent becomes doubly nervous about the prospect of competitive entry. While a large fixed investment might, once undertaken, lead a cable operator to feel immune to competitive pressures, the resulting temptation to raise prices will be offset by a sobering realization among the sophisticated: a large, fixed investment gives the careless incumbent more to lose. While municipalities emphasize the costs of overbuilding, they fail to perceive that such costs make established firms very dedicated to the preservation of their financially viable market by not inviting entry. They are thus constrained by their nonsalvageable investment, which is tantamount to a very large performance bond, forfeitable upon prices high enough or quality poor enough to invite successful competition. Under such conditions a monopolist might very well prefer the political constraints of franchise monopoly to the economic constraints of potential competition. ${ }^{147}$ The common interests of regulator and regulatee may be inconsistent, however, with the interests of the consumer of cable television services.

148 See Paul Kagan and Associates, The Kagan Census of Cable and PAY TV, Dec. 31, 1982, at 104, 113.

148 Pearce, supra note 133, at 26.

147 This may well explain why cable firms have been reluctant to oppose monopoly franchising: it is not at all clear that the benefits of constitutional protection (including freedom from locally imposed costs and franchise fees, for instance) outweigh the potential damage of increased competition. "The [National Cable Television Association] officially support]ed the cable firm plaintiff in Preferred Communications] but rank-and-file cabledom [was] ambivalent. 'There's no clear-cut consensus that the industry would benefit from a full-fledged challenge to the franchising process,' says the association's general counsel ...."Drummond, The Farrow Factor, 5 CHanneis of CoMm., June 1986, at 47, 47. 
The claim that market competition is an inadequate regulator of firm behavior in the cable industry has serious and presumably observable consequences. For this natural monopoly claim to be taken seriously, the threat of competitive entry must not be credible. Indeed, this constitutes the natural monopoly problem: incumbents may exploit their market position without fear of widespread consumer substitutions that would eliminate the monopoly profit. In identifying a natural monopoly problem, then, any particular market should be analyzed in terms of the ability of actual and potential competition to discipline market incumbents. For instance, the mere observation that cable television firms are most often seen to be spatially dispersed is not necessarily evidence of a natural monopoly.

In the cable television industry, much evidence reveals that competition is taken very seriously in its potential form. Municipal franchises are often granted for a fifteen to twenty year period. If a cable system were a natural monopoly, it would need only a head start to establish an overwhelming cost advantage over all potential rivals, and the majority of the franchise's span would be superfluous. At the very most, a firm need only receive exclusive franchise protection during the construction phase of its system, ${ }^{148}$ which generally stretches from two to four years. Instead of simply giving cable franchises short-term, head start protection, however, cities routinely grant long-term, nominally nonexclusive franchises, and thereafter refuse to issue competing franchises. In fact, municipal governments are much more likely to litigate against those competitors attempting to enter the cable market than they are to drop entry barriers.

The market competition between community antennae television (CATV) and satellite master antennae television (SMATV) reveals the attitude of many local governments towards competition. CATV is the traditional cable medium and has been challenged in recent years by SMATV. ${ }^{140}$ While SMATV systems originated as pay satellite channel hook-ups attached to apartment master antennae, the more modern systems can bring in over 100 channels and, by rewiring, can bring in any or all of CATV's video product. The remaining real difference between the technologies is that SMATV is a system located exclusively on private property, utilizing no public rights of way, utility poles, or under-

148 Even this protection is a denial that the system in question is a natural monopoly with respect to the franchised area, in which, under standard textbook assumptions of natural monopoly, an existing supplier may expand more cheaply than any newcomer. Hence, a "head start" is sufficient for market domination, as entry by additional firms would be implausible.

149 See infra notes 191-99 and accompanying text. 
ground conduits. Hence, it is commonly called "private cable."

According to industry calculations, this technology is directly competitive with CATV in high density areas where consumers such as apartment dwellers are found in groups of as few as fifty. ${ }^{150}$ An Indianapolis supplier, for example, is competing directly with a CATV system in a 220 unit apartment building "and apparently winning." Rather than being welcomed into the cable business by local authorities concerned with CATV's natural monopoly, however, SMATV operators have been obliged to "repel attempts by cities to regulate them."162 Municipal governments have vigorously litigated against private cable firms, including the successful Indianapolis SMATV firm, ${ }^{153}$ to prohibit them from entering markets. ${ }^{154}$ The comment of a large franchise cable operator, who believes more such litigation is needed, expresses the view of established CATV franchisees:

When the city has held our feet to the fire and is taking $5 \%$ [franchise tax] off the top and causing you to build a lot of non-productive assets, it infuriates you to see them not take action against someone who comes in and cuts into your business. . . . I think a lot of cities realize this person is also cutting into their business to the extent that the city takes revenue from the cable operator. ${ }^{185}$

This suggests that the cable franchise is understood in the industry as a grant of monopoly position in exchange for payments of taxes and facilities. That cities will attempt to restrict competition even where they receive an equal franchise fee percentage from the entrant, how-

${ }^{180}$ See SMATV: The Medium That's Making Cable Nervous, BroadCASTING, June 21,1982 , at 33,34 [hereinafter SMATV]. Jane Henry reports that by utilizing airwave links with microwave and satellite transmitters, "by the early 1990 s addressable SMATV systems will serve apartments and condominiums with as few as 25 units each," which should enable SMATV to "attract between 2 and 3 million subscribers by 1992." Henry, The Economics of Pay-TV Media, in VIDEo MEdia CoMPETITION 19, 55 (E. Noam ed. 1985).

181 SMATV, supra note 150, at 46. The CATV firm's penetration dropped from $80 \%$ to $20 \%$ when the private cable system overbuilt the GATV system, as the latter gained a $50 \%$ pay penetration. (No explanation is given for the vanished $10 \%$ ). See id.

182 Id. at 34 .

183 See Omega Satellite, 694 F.2d 119, 125-26 (7th Cir. 1982).

184 Other localities have attacked competition from private cable operators. See Hazlett, supra note 126, at 87-90 (discussing SMATV cases involving Indianapolis; Mankato, Minn.; Dallas; East Orange, N.J.; and Chicago); SMATV, supra note 150, at 46 (discussing disputes involving Meridian Township, Michigan; Dallas; Chicago; and New York).

185 SMATV, supra note 150, at 46 (comments of Trygve Myhren, chairman and chief executive officer of American Television and Communications Corp., a nationally integrated cable system operator). 
ever, is evident from the case of TM Cablevision v. Daon. ${ }^{\mathbf{1 5 6}}$ In this 1981 decision, a California court held that a real estate developer had the right to contract with a nonfranchised CATV supplier. While the California Constitution did not authorize exclusive franchises for cable television, the Vista city government had previously refused to license any operator save its chosen monopolist. The state court directed that a city cable franchise be issued to the new applicant, which had agreed to pay a city franchise fee equal to that imposed upon the incumbent. The monopolistic intent of city government thus appears to go through and beyond the capture of franchise fees. ${ }^{157}$

Conversely, some local governments, instead of erecting barriers to competitive entry, elect to open an incumbent's franchise to competition. According to the natural monopoly argument, such open competition will prove an impotent regulator of the incumbent's behavior. Experiences in a number of actual cable markets refute this view. In Presque Isle, Maine, for example, an established cable system was providing only twelve channels of service in the early 1980 's. ${ }^{158}$ Dissatisfied with this limited service, the city council decided to issue a competing cable franchise. Soon thereafter, the incumbent announced plans to upgrade to a fifty-four channel capacity complete with the traditional complement of satellite services. In the end, the second franchise decided not to enter the market against the upgraded incumbent. Nonetheless, the competitive pressure, activated only when the exclusive franchise arrangement was rendered obsolete, observably enhanced consumer welfare.

The Presque Isle experience is not unique. In late 1982, TeleCommunications, which operated the sole franchised cable system in Kearney, Nebraska, had wired but $70 \%$ of the city, although the system had been established in $1967 .{ }^{160}$ The company, providing just twelve channels of service, proposed a rate increase, subject to city approval, for its basic service package from $\$ 8.50$ to $\$ 11.50$ per month. When the city responded, however, by issuing a second franchise to Kearney Cablevision, Tele-Communications added basic and premium channels,

188 TM Cablevision v. Daon, 6 Media L. Rep. (BNA) 2576 (Cal. Super. Ct., San Diego County 1981).

${ }_{187}$ See Hazlett, Private Contracting vs. Public Regulation as a Solution to the Natural Monopoly Problem, in UnNatural Monopolies 71, 93-100 (R. Poole ed. 1985).

1s8 This discussion of the Presque Isle, Maine, situation is based on a June 5, 1984 telephone conversation with Earle Johnston, system manager of Group W Cable of Presque Isle.

${ }^{159}$ All information on the Kearney, Nebraska example is drawn from Declaration of John M. Mansell at 13, Tele-Communications of Key West, Inc. v. United States, Civil Action 83-3722 (D.D.C. 1983). 
expanded its cable plant by several miles, and dropped its request for a rate increase. Despite this action, Kearney entered the market and wired $80 \%$ of the city by mid-1983. In short order, the competition had brought consumers a choice between two firms, each offering more channels of basic programming than originally provided by the sole franchise, in addition to pay TV satellite channels and services.

Evidence also indicates that cable consumers enjoy enhanced services when direct competitors serve a market. A key variable is penetration: where higher penetration is realized, consumers have indicated by their patronage that the price/service package has improved. Hence, it is significant that when an existing cable operator in Bryan, Texas, was overbuilt by a second franchised rival in 1971, penetration rose from $60 \%$ to over $90 \%$ even as saturation ${ }^{160}$ rose from $65 \%$ to greater than $90 \%{ }^{161}$ Similarly, when an existing supplier in Allentown, Pennsylvania overbuilt in the early 1960 's, penetration rose from $80 \%$ to almost $100 \%$ and saturation, which had been a paltry $30 \%$, rose to 95\%, also due to "a wiring race."162 While consolidation of an existing overbuild lowers penetration slightly, ${ }^{163}$ an overbuilding entrant has never been identified as lowering total penetration. ${ }^{164}$ Hence, there seems little reason to fear overbuilds on consumer welfare grounds.

Potential entry is a viable, dynamic force for disciplining incumbents to act in the consumers' interests. ${ }^{165}$ If entry is possible, the proconsumer consequences of competition may be unleashed either by entry or by the appropriate price lowering and quality enhancing responses of the incumbent supplier. The mere existence of a sole supplier, regardless of how product and geographic markets are defined, does not necessarily indicate the existence of a natural monopoly problem. Indeed, where we observe incumbents reacting to potential entrants with improved cable packages, the evidence suggests that the survival of a motivated sole supplier actually reflects the market's

${ }^{160}$ Saturation is the ratio of homes in a franchise area that have cable available to them, or the proportion of a community "wired for cable." Penetration, on the other hand, is the percentage of those homes passed by cable that actually subscribe.

${ }_{161}$ See Booz Allen, supra note 58, app. at 5.1

162 See id. at IV-5, app. at 1.

${ }^{103}$ See id. app. at 16. The Salisbury, Maryland cable overbuild, consolidated in 1960 , saw penetration fall $5 \%$ from "about" $95 \%$ to $9.0 \%$.

16 This is simply an empirical endorsement of the proper interpretation of the sunk cost fallacy. See supra note 73 .

108 Even some regulators have been tempted to rely on the market's competitive structure to discipline firms in the consumer's interest. In Dade County, Florida a franchised cable firm may apply to compete in rival franchise areas after wiring 80 to $85 \%$ of its own service area. See Declaration of John M. Mansell, supra note 159, at 17-18. 
competitive structure. ${ }^{186}$

\section{Competition: To Attract Consumers or to SECURE'THE Franchise?}

\section{A. Political Competition and Consumer Welfare}

Cities and their consultants often contend that their franchising processes generate gains for consumers that would not otherwise be realized. Creating a legal monopoly through the franchising process and then exacting some part of the monopoly gains through various politically imposed requirements ${ }^{\mathbf{1 6 7}}$ can promote services that would not be provided in the absence of such a monopoly. ${ }^{168}$ This contention, however, confirms the suspicion that such services are not worth their cost to consumers; otherwise a private, unregulated firm would be able to provide them profitably. Moreover, the notion that government licensing and auctioning can encourage the provision of some additional services is not indicative of any special feature of cable television but is applicable to monopoly creation in any industry.

Suppose local governments could franchise laundromats. In exchange for the municipal laundromat franchise, a city or county might be able to obtain a new city hall, a convention center, or a basketball arena. Is this good public policy? The worthiness of the benefit is not here at issue; the efficiency and equity of the payment plan is. A government could always elect to provide these public facilities and to pay for them out of its general tax revenues. Under the franchising program, a government would specifically tax consumers of laundromat services with monopoly prices. As a general policy it is more efficient to allow open competition between laundromats and to raise revenues directly through general tax levies than to create a monopoly franchise that would restrict the supply of laundry services to monopoly levels in the short run, and that could deprive consumers of advantageous innovations in laundry technology in the long run.

It is not literally true that cable "operators predictably pass the cost to the subscribers." 169 Instead the monopoly franchise directly acts to limit both the actual and potential supply. The entry barrier created

${ }^{186}$ Interestingly, a similar implication is drawn when the incumbent responds by taking action in court or in city hall to deny legal admission to such competitors.

167 See Posner's comment supra text accompanying notes 123-24.

188 For instance, when examining six private overbuilt cable systems, Touche Ross concludes, "Public access and local origination services are very limited." Touche Ross \& Co., supra note 74 , at 30 .

160 Lee, supra note 17, at 909. 
by this implicit limitation on supply prompts prospective cable operators to offer cash and other valued resources to the local government and influential constituencies in an amount up to the discounted value of what is anticipated in excess of normal profits. Properly understood, it is the monopoly franchise itself, not the costly public access or community grant requirements contained in most municipal franchises, which increases the consumer's price for cable. ${ }^{170}$ Available evidence indicates that cable consumers tend in disproportionate numbers to be low to middle income individuals, implying that the cable tax burden is distributionally perverse. Webb reports that national data demonstrate that "low-income families spen[d] more dollars on basic cable than $\mathrm{d}[\mathrm{o}]$ middle-income families," and suggests that "low-income [urban] families may find that basic cable provides an inexpensive substitute for the other kinds of entertainment that the city offers." 171 These data support the conclusion that "special taxes on cable, such as municipal franchise fees, fall heavily on low-income groups."172

Moreover, whatever the income of the cable viewer, broader public policy concerns mandate that taxes be explicit and visible, rather than tucked away as an implicit, unquantified proportion of the cable customer's monthly charge. To the extent that politicians can appropriate resources without directly approaching citizens with a budgetary request or allocation, political bodies will tend to expend resources in excess of the spending actually desired by constituents, creating a classic free-rider problem. This can also be seen as an informational efficiency dilemma. Because monopoly prices are inherently hidden taxes in the

170 Lee does state the case correctly elsewhere in pointing out that when Phoenix, Arizona was opened to three citywide cable television competitors, "[t] $]$ he number of channels and nonrevenue-producing services that the competing firms offer[ed was] substantially less than the number that major market firms facing no competition offer." Id. at $874 \mathrm{n} .33$ (citation omitted). The firms did not foresee monopoly resources sufficient to pay for such services, and hence, the city could not obtain such services in pursuing its competitive franchising policy.

171 G. WEBB, supra note 101 , at 70.

${ }^{272}$ Id. Low-income individuals tend to be much more heavily concentrated in urban locations. City franchises routinely require universal service at uniform rates and may continue to do so even after deregulation under the Cable Communications Policy Act of 1984. "Nothing in this subchapter shall be construed as prohibiting any Federal agency, State, or a franchising authority from-(1) prohibiting discrimination among customers of basic cable service . . . Cable Conmunications Policy Act of 1984, § 623(f), 47 U.S.C. § 543(f) (Supp. III 1985). Consequently, a price discrimination scheme is created that favors affluent suburbanites residing on the relatively low density fringes of urban centers. "The most attractive areas for cable are those with more than seventy-five housing units per mile, and the best spots often have at least twice that concentration. 'People who live on two-acre plots are not good business targets for us,' says Monroe Rifkin, president of American Television \& Communications, the nation's second-largest cable company." Bernstein, supra note 86, at 67 . 
sense that taxpayers remain uninformed as to the costs of public expenditures and the distribution of these costs, there is no reliable mechanism by which the pattern of taxing and spending may be adjusted to democratic preferences.

Insofar as cities claim that monopoly franchising allows an increase in programming diversity, they make a counterintuitive appeal. ${ }^{173}$ How can limiting entry to one firm, when other firms stand ready and eager, increase diversity? Yet this claim is accurate in the following sense: a legal monopoly will often provide particular services that would not be forthcoming under more competitive conditions. Hence diversity is increased for those who value the additional services subsidized by the monopoly franchise arrangement, but not through the market process of consumers voting with their dollars. Like most attributes pleasing to consumers, diversity is in the subjective eye of the beholder. The Soviet Union could create a Ministry of Diversity, and promote new and different perspectives as determined by the Ministry. One suspects that these promotions, however, would have little to do with the citizenry's preferences for innovative thought. The advantage of open market selection is that it spontaneously distributes rewards in the form of profits to those entrepreneurs who most efficiently meet consumers' preferences for diversity. The political selection of product or service, whether conducted by panel, committee, council, or public hearing, cannot match the vastly more efficient selection that takes place in the open marketplace. ${ }^{174}$

173 "[A] primary objective, and result, of Sacramento's franchising process is an increase in the diversity of communications within the Sacramento community. Such diversity is enhanced by (among other things) large channel capacity, public and leased access, community use, and the SCT [Sacramento Community Trust] system of grants." Memorandum in Opposition to Plaintiff's Motion for Preliminary Injunction at 45, Pacific West Cable Co. v. City of Sacramento, No. GIV S-83-1034 MLS (E.D. Cal. May 9, 1985). The cost only of the cash grants provided for in the 1984 Sacramento cable franchise agreement to encourage diversity through SCT awards amounts to $\$ 1.04$ per customer per month. This amount excludes franchise fees, and the capital costs of excess channel capacity and of physical facilities. See Declaration of Frederick Bolte at exhibit $15 \mathrm{~A}$, table 2 , in id.

174 A first amendment question arises as well. The Ninth Circuit addressed just this question in Preferred Communications, Inc. v. City of Los Angeles, 754 F.2d 1396 (9th Cir. 1985), affd., 106 S. Ct. 2034 (1986). Although the city claimed that the plaintiff had no right to construct its own cable system and that the plaintiff's right to free speech was fully protected by the general availability of mandated public access program space available for its use on the franchised monopoly cable, Judge Sneed disagreed:

We reject the contention that the City's access requirements provide complete protection for the exercise of expressive rights. Arranging programming for an entire cable television system entails engaging in a wide variety of protected activities. Substituting the chance to share a few mandatory access and leased access channels with others for the right to 
Forced by federal policy to abandon the price regulation argument for monopoly franchising, local governments increasingly assert not that franchising will produce an efficient quasi-competitive outcome but that it will simply redistribute the monopolists' profits in a socially desirable way: the franchise will be issued in exchange for a commitment to provide various nonprofitable services. ${ }^{175}$ Such an exchange does not eliminate monopolist inefficiency, but simply redirects monopoly profits. Moreover, it transfers these profits in a form that wastes economic resources. One expert witness presented the diversity argument as follows:

The franchising process typically induces not only added channel capacity, but also commitments of financial support for local programming that would not be made if there were open market entry without franchising. Operators would generally not make significant investments in local origination and access programming because they generally do not believe that there is a sufficient financial return on investment in these services. They make such commitments primarily to increase their chances of selection in franchising competitions. ${ }^{176}$

This argument is of crucial importance to the economic defense of

operate an entire cable system necessarily diminishes PCI's opportunity to engage in such protected activities. A law allowing free expression in public parks only for a few minutes at 6 a.m. hardly provides an adequate replacement for the right to free, untrammeled debate in that forum. . . . ... The City's argument is hard to distinguish from an assertion that a law prohibiting Mr. X or Mrs. $\mathrm{Y}$ from publishing a newspaper is valid, so long as each is provided an adequate space to print his or her message in already existing newspapers. Obviously, such a law would be invalid.

754 F.2d at 1410 (footnote omitted).

${ }^{175}$ In an exclusive franchising situation, nonprice controls can at best channel some portion of the monopolist's excess returns to various constituencies. For instance, a city government could theoretically auction a franchise to the firm bidding the highest lump sum or the highest present value of a periodic payment stream. The monopolist willing to pay the most would be the one planning to charge profit-maximizing monopoly prices. Under this scenario, the city government could take the excess returns for itself, but the result would still be classic monopolistic inefficiency, because marginal customers are priced out of the market even where they are willing to pay above the firm's marginal, or even average, costs. In any case, as was noted earlier, such an auction is illegal under federal law. See generally Cable Communications Policy Act of 1984, § 622(b), 47 U.S.C. $§ 542$ (b) (Supp. III 1985) (limiting franchise fees to 5\% of gross revenues per year); G. WEBB, supra note 101, at 159-78 (discussing the franchising process and taking the situation in Philadelphia as a specific example).

${ }^{178}$ Declaration of Jay C. Smith at 18-19, Group W Cable v. City of Santa Cruz, No. C-84-7546-WWS (N.D. Cal. hearing date Aug. 30, 1985). 
franchising because it forthrightly abandons any pretense of efficiency. In noting that the municipal auction encourages the provision of services not worth their cost to consumers, the argument actually advocates inefficiency as a justification for ${ }^{-}$franchising. In contrast, unregulated cable operators have every incentive to supply all services, but only those services, for which consumers are ready to pay. ${ }^{177}$

In an efficient market, suppliers give consumers just as much product as consumers are willing and able to buy; to oversupply one market (i.e., to push more product on consumers than they can "afford") is to undersupply some other market or markets, with the result that consumer satisfaction will not be maximized. This latter allocation of resources, then, is classically inefficient in that it takes scarce resources out of relatively valuable uses and diverts them to uses in which they produce smaller consumer benefits.

The unfranchised cable television market is particularly efficient at supplying exactly those services for which consumers will pay. Unlike some other video media, cable programming is easily excludable; the public good or free-rider problem is thereby reduced. In contrast, a broadcast television station may have trouble supplying an expensive operatic production to its audience, for instance, even if sufficient demand exists to justify its cost, because the station will have difficulty charging opera devotees for the shows that they desire. The great advantage of cable is that, through subscriptions, tiering, premium channels, and pay per view, suppliers can more easily identify and capture particular demands. As Eli Noam notes:

$\mathrm{A}[\mathrm{n}]$... advantage that cable affords over traditional television is that it permits the operator to impose a charge for the viewing of specific programs. The possibility of such per-program pay-cable revolutionizes the program offering on cable because it permits programs and services with much higher production budgets. ${ }^{178}$

Noam concludes by observing that cable is so efficient in extracting payments in accord with the intensity of consumer demand that

${ }^{177}$ A rational profit-maximizing monopolist will elect to serve any submarket in which marginal revenues gained exceed marginal costs incurred, just as a competitive firm would so choose. The monopolist might also, however, be able to raise prices above competitive levels, thus diminishing consumer demand. But it would be unprofitable for the monopolist to impose a supra-competitive price that eliminates the entire submarket. In other words, a monopolist would rationally serve any submarket that a competitor would serve.

${ }_{178}$ Noam, Local Distribution Monopolies in Cable Television and Telephone Service: The Scope for Competition, in Telecommunications Regulation Today AND TOMORROW 362 (E. Noam ed. 1983). 
"[i]ndeed, one can expect the most desirable programs, i.e., those whose consumer surplus is highest, to be largely siphoned from free television and moved to pay-television."178

The significance of Noam's conclusion should not be overlooked. To argue that cable firms would not, in a competitive environment, provide the sorts of services that local governments select clearly attests to the inefficiency generated by the franchising process. Since the profit-maximizing strategy in a competitive environment is to provide all increments of capacity and programming that consumers value more than the opportunity cost, political selection of cable services has a negative impact on social welfare by imposing the supply of services worth less than their cost.

The level of economic waste induced by the franchising process is apparently significant. If, as cities assert, the cost of supplying cable services consists largely of sunk costs, and municipalities must continually police franchisees to assure compliance with franchise terms regarding the provision of public access and local origination programming, for example, the reluctance of cable firms to offer such low variable cost services must demonstrate a virtual vacuum of demand. ${ }^{\mathbf{1 8 0}}$

The legal stance of both franchiser and franchisee belies any economic efficiency rationale for monopoly franchising. The municipalities argue that they must issue exclusive franchises conditional upon the public interest, but possess no mechanism for eliminating monopoly pricing, and no objective, nonpolitical process by which to measure the consumer value of forced service requirements. The cable firms holding franchises assert that cities should issue exclusive franchises without which the firms could not deliver the full complement of nonremunerative cable services. ${ }^{181}$ The cities concur, and dutifully defend their mo-

$178 I d$.

180 Local regulators often claim that their jobs consist largely of enforcing compliance with franchise terms. Susan Herman, Los Angeles' top cable administrator and formerly an assistant to New York City's cable director, said: "When I used to go home in New York to view my cable, it was not to watch it. It was to flip through to ensure that what they were obligated to carry they were carrying . . . That was really boring." Decker, Doing Battle in the L.A. Cable Wars, L.A. Times, Oct. 13, 1985, at II1 , col. 1 , II-10, col. 1 .

181 When urging rate deregulation, the industry argues that it is highly competitive with broadcast television, SMATV, DBS, and home videos, and that it has no monopoly power.

Thomas Wheeler, president of the National Cable-Television Association . . . said only a little more than half of the 35 million homes with access to cable-TV subscribe to it, so the service clearly isn't essential. Cable-TV is far from a monopoly, and its prices will be kept in line by competition from commercial and public TV, radio, video cassettes, movies and new technology in the offing, he contends. 
nopoly franchising authority in the courts precisely on these grounds.

Yet this sequence of litigative causality gives the lie to the efficient regulation argument. Natural monopoly is considered problematic because the incumbent producer in the market has cost advantages that overwhelm potential competitors such that prices remain monopolistic without inviting entry. Cable monopoly franchises, however, may squander the entire sum of excess returns on politically demanded services while the firm remains profitable, that is, recovers both its variable and fixed costs. For the firm to insist, and for the city to agree, that the "solution to natural monopoly" cannot be sustained without a legally enforced long-term monopoly franchise, must mean that the city demands more for its franchise than the free entry, unfranchised monopolist could afford. The municipal policy of erecting legal entry barriers so as to enforce the contract for certain nonremunerative services actually results in the creation, rather than the dissipation, of monopoly power. ${ }^{182}$

\section{B. Actual and Potential Competition in an Open Market for Cable Television}

The fact that there is some cost advantage to spacing firms geographically should have little bearing on public policy. ${ }^{183}$ As Owen and Greenhalgh suggest, firms that are willing to compete should be allowed to do so. ${ }^{184}$ Just as there are rarely four convenience stores on the same corner, or two pet stores in the same shopping center, the proximity of competition is clearly an important element in a cable firm's profit-maximizing investment decision. But importantly, not only does the cable entrant internalize the costs of overbuilding; it reaps the net advantages as well. If the firm has a substantially better product than the incumbent, or a more efficient business organization, or both, the duplication cost may well be outweighed by an efficiency gain and

Crock, supra note 122 , at 30 , col. 5 .

182 This analysis does not demonstrate a total absence of monopoly power in a free market, only that it is insufficient to subsidize the effective payment required by the franchising authority. When a study that assumes natural monopoly claims support for exclusive licensing based partly on the fact that "[i]nterviews indicate that municipalities consider a single system operator more likely to fulfill franchise commitments," Booz Allen, supra note 58, at IV-18, it reveals that the discipline of open market competition is a tighter proconsumer constraint on firms than are the local regulators. Moreover, it logically follows that political agents have an interest in suppressing competition for consumers, to better enable political exchanges and cross-subsidies to be effectuated.

18s See Owen \& Greenhalgh, supra note 94, at 76.

184 See id. at 78. 
the firm will rationally choose to invest. ${ }^{185}$ The mere possibility that such a calculation to enter could be made by an outsider will tend to deter an insider from monopolistic behavior. The existence of just one pet store per shopping mall neither implies monopoly, nor suggests public franchising; any foreclosure of the possibility of new pet shops moving into the mall would lessen the threat of potential competition, which effectively serves to regulate pricing practices.

Any credible natural monopoly argument must also address the issue of cross-substitution for the services that cable firms supply. If ready substitutes abound, then no true monopoly is said to exist, in that even a sole cable supplier will face effective competitive pressure from suppliers of rival products. Hence, consumers are protected from exploitation under an open market policy.

Proponents of municipal cable franchising, however, often ignore cross-substitution altogether and aim to convince courts and legislative bodies that a market with only one cable firm is prima facie evidence of natural monopoly. In the federal regulatory context, however, substitutes are to be considered in any analysis of cable television markets. In the Cable Communications Policy Act of 1984, Congress specifically instructed the Federal Communications Commission (FCG) to identify the geographic markets in which effective competition existed. ${ }^{188}$ Such markets were slated for basic rate deregulation. Rather than simply undertake an analysis of directly overbuilt cable markets (the pro forma approach to competition taken by municipal governments), the FCG focused on traditional broadcast television as a competitor to cable. In declining to extend its analysis beyond this one potential source of rivalry, the Commission deemed effective competition to exist in any community where three B-contour grade television signals were received. ${ }^{187}$ Thus, federal policy, as established by Congress and the

185 Overbuilding is likely to be the market response in such circumstances; importantly, it is the socially efficient response. See supra notes $139-40$ and accompanying text.

188 See Cable Communications Policy Act of 1984, $\S 623(\mathrm{~b})(1), 47$ U.S.C. $\S$ 543(b)(1) (Supp. III 1985).

${ }^{187}$ The Cable Act specifically charges the Commission with the responsibility of defining effective competition ....

We ... conclude that the existence of three or more off-the-air broadcast signals in the cable market provides viewers with adequate programming choices and presents an effective constraint on the market power of a cable system in the provision of basic service. . . . Accordingly, a cable system will be considered to face effective competition whenever the franchise market receives three or more unduplicated broadcast signals.

FCC Report and Order, 50 Fed. Reg. 18,637, 18,648 I 91, 18,650 I 100 (May 2, 
FCC, clearly regards the presence of intermedia competition as central to the issue of monopoly versus competition in cable television.

While the FCG felt no compulsion to go beyond consideration of traditional broadcast television as a rival to cable television, the number of additional sources of intermedia competition are impressive. ${ }^{188}$ In fact, these alternatives to cable have led one group of prominent cable industry analysts, without consideration of the feasibility of cable-oncable competition, to conclude that "cable systems lack the economic and legal attributes of a natural monopoly and that all major markets and submarkets in which cable competes or is likely to compete are workably competitive with a number of alternative suppliers."189

In investigating the monopoly question with regard to cable television, these analysts preceded the FCC in concentrating on the availability of intermedia substitution. While "it is physically possible to build a second cable system," the analysis notes that other delivery systems utilizing "broadcast, microwave, or telephone distribution may be less costly." "190 Given the importance of contestability in current monopoly theory, an examination of rival video and information services is crucial. If high fixed entry costs are no longer considered sufficient to demonstrate the presence of a natural monopoly, any allegation of natural monopoly must demonstrate a dearth of potential competitors with low sunk costs. The accepted economic analysis, then, would require a

1985) (footnote omitted). The report goes on to define a signal: "[A] signal will be counted for purposes of effective competition if it places a predicted Grade B contour over any portion of the cable community or is significantly viewed within the cable community." Id. at 18,651 II 107 (footnote omitted). Eighty-seven percent of cable systems have been released from rate regulation under the effective competition standard. See D. Patrick, Cable's Brave New World 2 (speech at the Western Cable Show, Anaheim, Cal., Dec. 5, 1985).

${ }_{188}$ Indeed, the 1985 FCC report on effective competition noted the importance of nonbroadcast cable rivals.

In adopting this definition [of effective competition], we do not mean to minimize the importance of the various alternative sources of video programming such as multipoint distribution services, direct satellite reception, and video cassette recorders. Such services are significant providers of video programming services and do, in fact, offer competition to cable services.

FCC Report and Order, supra note 187, at 18,649 I 98 (footnotes omitted); see also Note, Defining the Relevant Product Market of the New Video Technologies, 4 CaRDOZO ARTS \& ENT. L.J. 75, 101 (1985) (footnotes omitted) ("Studies indicate that consumers do not distinguish among the different technical methods that produce a picture on the television screen. Similarly, consumers do not differentiate ... between a technology that can deliver 100 channels of programming and a technology that can deliver five extra channels.").

188 Shooshan, Jackson, \& Kahn, Cable Television: The Monopoly Myth and Competitive Reality 3 (April 1982) (unpublished manuscript).

${ }_{190}$ Id. at 6-7 (footnote omitted). 
showing that alternative suppliers are nonexistent, or if present, possess characteristics consistent with the existence of natural monopoly themselves. The most important of these characteristics would be a level of capital fixity sufficient to create large exit costs.

Excluding broadcast television, the primary sources of competition to cable are: satellite master antenna television (SMATV), satellite television (TVRO), direct broadcast satellite television (DBS), multichannel multipoint distribution systems (MGTV), and video cassette recorders (VCR). I will briefly explain each technological substitute and its competitive relationship to cable television.

SMATV: Hooking a satellite receiver disk up to the master antenna of an apartment, condominium, hotel, trailer park, hospital, or other relatively high-density housing complex constitutes a form of direct competition with cable television in such submarkets. In fact, there can be no doubt that these private cable systems are perceived as a competitive threat: city governments and monopoly cable franchisees have repeatedly challenged SMATV competitors in court. ${ }^{191}$ Particularly interesting are instances where an SMATV supplier has used microwave technology to beam satellite signals from one wired building to the next, prompting the local government to claim regulatory jurisdiction over the public rights of way several stories above the ground. As the New York Times noted, "Local governments . . . have in recent years grown worried about the proliferation of master antenna systems, because such systems are often used by landlords or condominium associations in lieu of cable, reducing the cable operators' revenues and hence the payment of local franchise fees." 192

Interestingly, the FCC has defended SMATV's ability to compete against traditional cable services. The Commission intervened to bar local regulation of satellite systems located on private property: "We're not saying the states can't regulate satellite dishes from a standpoint of public safety or zoning, but we are saying they can't regulate or prohibit S.M.A.T.V. service simply because it's a competitive threat to cable television."193

191 See supra note 154.

192 F.C.C. Bars Local Satellite-TV Rules, N.Y. Times, Nov. 9, 1983, at D10, cols. 1,2 .

${ }^{193}$ Id. at D10, col. 3 (comments of James C. McKinney, chief of the FCC's Mass Media Bureau). One commentator states bluntly: "Most cable operators would be very happy to squelch SMATV, whose operators often build within a cable system's supposedly exclusive franchise area. The cable industry has persuaded legislatures in 11 states ... to keep SMATV operators from striking exclusive agreements with managers of so-called multidwelling-unit complexes." Traub, SMATV: Fighting Cable with Cable, 5 Channels of Comm., Nov./Dec. 1985, at 43 (1986 Field Guide).

GATV clearly recognizes SMATV as being an effective competitor. Whereas the 
SMATV's ability to compete with traditional cable is precisely what has distressed some local governments. The largest private cable system has been established in the Bronx at Co-Op City, the nation's largest apartment complex, with approximately 15,000 apartments and 60,000 residents, which contracted for a 108-channel state-of-the-art system. ${ }^{194}$ New York Gity's CATV franchise for the Bronx claims its market is not viable if it must compete in the borough-and so the city and state have brought legal actions to halt the private cable system. ${ }^{105}$ SMATV suppliers are so competitive that a local government's ability to arrange political trades through franchising is seriously threatened by the existence of such systems. "The presence of SMATV operators in franchise areas angers many cable operators, who expect the assistance of municipalities in getting rid of unwelcomed competition."198

With federal policy now tilted toward free entry, however, competitive behavior can be observed. In Pompano Beach, Florida, Telsat Cablevision, a subsidiary of Florida Power and Light offering SMATV, has budgeted $\$ 24$ million to wire "at least 150,000 dwelling units by autumn, 1988."197 The system's manager "says he enjoys competing head-to-head with cable systems. . . . It's not unusual for our prices to be half of what the franchised cable operator is charging. We can offer 25 channels of basic services for $\$ 7.00$ or $\$ 8.00$ a month, and that includes extra outlets."198 Meanwhile, cable monopolists in Florida paradoxically claim that competing "with the fifth largest investorowned utility in the country ... does not lend itself to free and open marketplace competition from the cable operator's point of view."199

rivalry of CATV and SMATV for landlords' business could certainly create a competitive outcome in multidwelling submarkets, the eagerness of legislative bodies to bar such competition reveals an intent to advance special interest protectionism at the expense of efficiency.

194 See SMATV, supra note 150 , at 33.

185 Satellite Television of N.Y. Assocs. v. Finneran, 579 F. Supp. 1546 (S.D.N.Y. 1984) (granting an injunction to prevent enforcement of state commission's cease and desist orders restraining construction of SMATV system at Co-op City in the Bronx).

186 See SMATV, supra note 150 , at 46.

197 Southern Discomfort, CaBle Television Bus., Dec. 1, 1985, at 12.

198 Id.

180 Id. Another writer observes:

[SMATV's] potential for growth is enormous. Cablecom, Inc., a Chicago SMATV operator, provides pay-TV services to some of the city's most prestigious lakefront residences, where cable operators have yet to string their wires. The company sells a six-channel package, including movies and news, for $\$ 19.95$ a month. But it is developing a 60-channel 'addressable' SMATV system, which would allow viewers to select specific programs on a pay-per-view basis.

Wines, Cable Companies Fall Victim to Overpromises, Competition for Viewers, 16 NAT'L J., Feb. 18, 1984, at 314, 316. Another commentator explicitly describes 
TVRO: Satellite dishes, which are typically installed in the backyards of customers, now offer a wide range of television services. The prices of such TVRO (television receive only) dishes have fallen dramatically since the mid-1970's. "Complete home receiving systems, which once sold for as much as $\$ 36,000$, now cost as little as $\$ 800$. Since the beginning of 1985 their number has been increasing by at least 40,000 a month."200

TRVO represents a close substitute for cable television. MalarkeyTaylor Associates, a cable industry consulting firm, finds that "onethird of the total home dish systems sold today are used in cabled areas."201 Moreover, dishes are evidently less costly than GATV in sparsely populated neighborhoods; cable franchisees are moving to "wire" such portions of their franchises with TVROs. In one survey, $14 \%$ of cable operators reported that they planned to enter the TVRO market during 1986, despite the fact that "as little as two years ago TVRO sales were considered virtual enemy territory."202

SMATV's ability to compete with traditional cable:

MATV competition has already been felt by several MSO's [multiple cable system operators] with urban franchises. In Dallas and Houston, franchise winner Warner Amex has been forced to build a temporary "head-end" to provide immediate service as a counter to MATV activity. MATV is also a competitive force in Tucson, Denver, Miami and New York. Whereas cable companies may be willing to forego multiple dwellings in sparsely populated areas, they stand to lose too much-perhaps $20 \%$ to $30 \%$ of their market area-in the major cities.

The Home Video \& Cable Y.B., 1982-83, at 33.

200 Barbieri, Backyard Dishes: DBS By Any Other Name, 5 Channels of Comm., Nov./Dec. 1985, at 54 (1986 Field Guide). Another source estimates that monthly sales total approximately 60,000 TVROs per month. See TV Mushrooms in the Backyard, Trme, Sept. 16, 1985, at 56.

One reason for impressive sales is piracy of signals. On Jan. 15, 1986, however, Home Box Office (HBO) and Cinemax began scrambling their satellite-relayed signal so that an expensive (\$395) decoder is required, in addition to monthly charges, for reception via backyard satellite dishes. Other pay television channels were also expected to begin signal scrambling (encryption) by the end of the year. Nevertheless, more than 100 channels are still easily receivable using TVRO dishes. See Fantel, The Dish Owners vs. the Scramblers, N.Y. Times, June 15, 1986, at II-30, col. 1; Peterson, Scrambling of Signals Today Thwarts TV Dish Antennas, N.Y. Times, Jan. 15, 1986, at A1, col. 1. Most important here is the essential competitive issue: cable television is supposedly a natural monopoly because firms must make a large nonsalvageable capital investment that arguably deters competitive entry. Placing TVRO dishes in competition with traditional cable, however, does not require a prohibitive capital investment. If significant barriers to entry in satellite programming existed, this would entail a market power problem in programming, not in receiving.

${ }_{201}$ Clayton, Home Earth Station Makers Gear Up to Meet Demand from Cable Operators, Multichannel News, Dec. 2, 1985, at 29.

202 Firms Urge Cable On, Cable Television Bus., 1985 Special Edition, at 10; see also Clayton, supra note 201, at 29 (discussing cable operators entering TVRO business). Rural telephone and electric co-ops have also entered the satellite dish business. See Evancho, Clashing With Co-Ops, Satellite Dealer, Nov. 1985, at 39. 
The Canadian government, in fact, once prohibited its citizens from owning TVROs. ${ }^{203}$ The government ban was imposed, partly in response to a request from Ganadian cable operators who "[l]ike their U.S. counterparts . . considered [the home satellite TV industry] a threat to their monopolistic position as carriers of premium signals." Due to widespread noncompliance, the Canadian prohibition against ownership of TVROs was repealed in 1983. ${ }^{205}$

$D B S$ : Direct broadcast satellite television has already failed once as a competitor of cable television. But rapidly changing costs, due to a dynamic technology, have induced several large firms, including the country's largest cable operator, to re-enter the market. ${ }^{208}$

DBS's technical advantage over TVRO is that the former utilizes a stronger transmission frequency and thus may employ smaller, cheaper dishes. Indeed, the standard DBS dish is just two to three feet in diameter, as opposed to the typical TVRO dish, which is six to ten feet in diameter. Eleven DBS suppliers are now planning to market pay service packages consisting of up to sixteen channels each. As one leading cable industry executive sees the competitive threat:

The future may not be cable friendly. The low cost and early release of video movies has quelled the excitement of past years for cable movies. Before 1990, several DBS services will appear with the same entertainment offerings as are 74.

${ }^{203}$ See Masters, A New Canadian Club, Satellite Dealer, Nov. 1985, at 68,

204 Id.

205 See id.; see also Amendment of General Radio Regulations, Part II, 117 Can. Gaz. 2087, 2088 (May 25, 1983) (Registration SOR/83-422, May 12, 1983) (explanatory note) ("This amendment exempts certain persons from the requirement to obtain a licence under the Radio Act in order to possess and use earth stations for the reception of a radio or television programming signal transmitted by a satellite operating in the fixed satellite service.").

In the United States, the FCG has ruled that "the nation's cities . . . cannot outlaw satellite receiving dishes as a way to promote the growth of cable TV." Cities Can't Ban Dishes to Help Cable's Growth, L.A. Times, Jan. 16, 1986, at VI-11, col 3; see also In the Matter of Preemption of Local Zoning or Other Regulation of ReceiveOnly Satellite Earth Stations, No. 85-87, FCC 86-28 (slip op. released Jan. 5, 1986) (LEXIS, Fedcom library, FGG file); Stuart, F.C.C. Limits Rules Over TV Receivers, N.Y. Times, Jan. 15, 1986, at A16, col. 1. This FCC decision suggests that the federal agency perceives a monopolistic intent on the part of local authorities who have attempted to restrict use of such dishes through zoning regulations.

208 "A number of large cable operators, including the largest, Tele-Communications, Inc., are already planning to sell DBS services to unwired communities at prices that will compete with cable- $\$ 6$ to $\$ 20$ a month." Barbieri, supra note 200 , at 54 . Barbieri also notes that many believe that the initial failure of one DBS supplier, United Satellite Communications, which sold a five channel service to fewer than 15,000 subscribers and incurred losses of $\$ 53$ million in 17 months of operation between 1983 and 1985, was die to mismanagement. See id. 
available to cable. On the $\mathrm{Ku}$ band, the antenna, receiver and decoder package will be under $\$ 500$, far less than current cable subscriber values."207

MCTV: Multichannel television (MCTV) has developed as a replacement for multipoint distribution system (MDS) television. The old, single channel MDS television and subscription TV (STV), which send a scrambled, pay channel over a normal, off-air UHF signal, have been for the most part unable to compete with cable television, VGRs, and TVROs. For instance, STV operators recently pulled out of Chicago, Cincinnati, and Miami, leaving "New York, Los Angeles, and Washington as the only big cities with STV service."208 From 1.5 million subscribers early in this decade, current viewership has declined to less than $300,000 .^{200}$

Multiple pay channels delivered by microwave transmission supplant the single channel pay service as a far more viable video service, often called wireless cable. The FCC awarded eighteen licenses for four-channel service in nine major markets in September, 1985, and has plans to award hundreds more. ${ }^{210} \mathrm{MCTV}$ providers have already begun leasing spectrum allocations from nonprofit institutions, which own the rights to Instructional Television Fixed Service (ITFS) bands, ${ }^{211}$ allowing MCTV broadcasters to begin operations in Washington, San Francisco, and Las Vegas even prior to the FCC's spectrum lottery. ${ }^{212}$

While some industry sources claim that MCTV is primarily limited to serving as an inexpensive substitute for CATV in uncabled areas, ${ }^{218}$ the relevant market dynamics belie the logic of this claim. As MCTV providers jump first into the uncabled areas of major urban regions, their ability to preempt CATV successfully becomes evident. According to the director of marketing for one MGTV firm in New York City, "MCTV is not going to displace cable in cabled Manhat$\tan$. . . but it may 'obviate the need for it' in New York's outer boroughs (Queens, Brooklyn, Bronx, and Staten Island), which are not

207 Moving Beyond the Basics, Cable Marketing, Dec. 1985, at 16, 30 (comments of Isaac $S$. Blonder, chairman of the board of directors of Blonder-Tongue).

${ }_{208}$ Barbieri, STV: R.I.P., 5 Channels of Comm., Nov./Dec. 1985, at 32 (1986 Field Guide).

${ }_{200}$ See id.

210 See Wolf, Multichannel MDS: The Start of Something Small, 5 CHAnneLS of CoMm., Nov./Dec. 1985, at 34 (1986 Field Guide).

211 See id.

212 See id.

213 "The proponents of [MCTV] now concede that their medium can never go head-to-head with cable; its niche is among the several million homes cable won't reach." Id. 
and may never be wired." 214 The fact that MCTV could "obviate the need" for cable television suggests that the service imposes a competitive constraint even on established CATV systems, particularly those in Manhattan, where MCTV firms may utilize existing channel frequencies and exploit economies of scale in advertising and marketing. Essentially, where a CATV operator attempts to indulge in apparent monopolistic behavior, MCTV suppliers could descend on the market without investing extensively in nonsalvageable capital. Thus, even markets with established GATV systems may be considered competitive in the contestability sense. Hence, the first mover into a market may continue to be its sole supplier, but may engage in monopoly pricing or other behavior that restricts output only at the risk of encouraging entry by low sunk-cost competitors. The fact that CATV may be unable to enter those markets where MGTV was the first entrant implies the vitality of MCTV as a rival to cable. ${ }^{215}$

VCRs: The video cassette recorder, perhaps the most significant competitor of cable television, foregoes satellite and wire altogether. Video cassette recorders are currently in $35 \%$ of all U.S. households, ${ }^{216}$ and "[b]y conservative estimate, 55 percent of U.S. homes will have VCRs by the end of 1990."217 Sales are currently brisk: 11 million VGRs were sold in America during 1985 as prices dropped to as low as $\$ 199$ per unit. $^{218}$

Academic research has revealed evidence on the substitutability of VGRs for pay cable programming. In a 1984 FGC study, Jonathan D. Levy and Peter Pitsch uncovered statistical relationships implying "strong support to the proposition that VGR's and cable are substitutes." 18 The authors additionally found evidence that CATV and broadcast television are substitutes, ${ }^{220}$ while broadcast television and

214 The Expanding World of Multichannel TV, Broadcasting, Mar. 11, 1985, at 38 (remarks of Bruce De Court, marketing director of Pay TV). De Court further asserts that his firm's service "will be extremely competitive with cable." Id.

${ }^{215}$ There is nothing that prevents MCTV "overbuilds" of CATV systems. "In the Milwaukee market, Movie Systems Chairman Jack Stephens said he is pricing his service to compete head-to-head with the cable operators in and around the city for new subscribers." Id.

210 See Solomon, Cable TV is at a Crossroads-Trying to Figure Out What It Ought to Be, 17 Nat'L J., Nov. 2, 1985, at 2478, 2482.

${ }^{217}$ Lachenbruch, VCRs: From Gizmo to Household Word, 5 Channels of Comm., Nov./Dec. 1985, at 74 (1986 Field Guide).

218 See id. at 75.

219 J. Levy \& P. Pitsch, Statistical Evidence of Substitutability Among Video Delivery Systems 27 (Apr. 26, 1984) (available through the FCG Office of Public Affairs).

${ }^{220}$ See form cover letter from FCC accompanying J. Levy \& P. Pitsch, supra note 219 (on file with the University of Pennsylvania Law Review). 
VCRs are complements. ${ }^{221}$ Hence, when television broadcast stations are joined with VGRs by the consumer, as is typical, a strong competitor to cable emerges. ${ }^{222}$

For some consumers, a net convenience advantage may accrue to VCRs, since the inconvenience of renting and returning a cassette can be more than offset by the enhanced control over selection afforded by large rental inventories and by the complete control the consumer exercises over viewing times. The time costs of renting are being reduced as supermarkets, gas stations, and convenience stores enter the video cassette rental market. ${ }^{223}$ As player-only machines enter the market at a price of about $\$ 100,224$ and as cassette rental prices fall to between $\$ 1.00$ and $\$ 2.00$, the cable industry will further react to competition that is already causing $\mathrm{HBO}$, the top domestic pay service, to pursue the costly strategy of showing first run, big event programming, and leading GATV systems to discount packages of pay channels. ${ }^{225}$

This survey does not exhaust the list of potential technological rivals to CATV. For instance, low power television (LPTV) may offer increasing competition. Conceived in 1980, LPTV entails the licensing of as many as 4000 additional broadcast television stations confined to concentrated viewing areas. ${ }^{226}$ These signals may broadcast pay channels or programming supported by commercials. Thus far, 320 licenses have been granted and the FCG has 40,000 applications on file. ${ }^{227}$

221 See id.

222 This conclusion is endorsed by a recent marketing survey, which found that "[c]able subscribers who have complaints about their service and are not satisfied with a cable system's customer service are highly likely to own VCRs, to be heavy tape renters and to record programs off the air ... ." Study Finds VCR Owners Dissatisfied with Cable, Multichannel News, Dec. 2, 1985, at 75.

${ }_{223}$ See, e.g., Picking Up a Movie, Wall St. J., Mar. 5, 1986, at 35, col. 3 (citing a survey showing that $83 \%$ of consumers who buy or rent video cassettes do so in video stores, $16 \%$ in discount stores, $11 \%$ in department stores, $9 \%$ in grocery stores; figures sum to more than $100 \%$ because consumers often shop for cassettes in more than one type of retail outlet); Cieply, Despite Movie Rental Boom, It's 'The End' for Many Shops, Wall St. J., Apr. 1, 1985, at 25, col. 1 (stating that many small retail businesses-dry cleaners, drugstores, photo-finishing shops and even trailer rental shops-are seeking to add video rentals to their ongoing businesses).

${ }_{224}$ See Coates, Ad Agency Makes VCR Predictions, Elecrronic Media, Dec. 2, 1985 , at 50.

${ }_{223}$ See Solomon, supra note 216, at 2482 (describing HBO's efforts to provide programming that is unavailable on prerecorded cassettes, such as concerts and boxing matches, and the plan of a chain of cable franchisees in California to offer a package of four pay television channels at a reduced monthly service charge).

${ }_{228}$ See Couzens, LPTV: Queuing Up For A Long Shot, 5 Channels of Comm., Nov./Dec. 1985, at 28 (1986 Field Guide).

${ }_{227}$ See id. Not included in this analysis of intermedia competition analysis is rivalry from the telephone industry. Such rivalry is prohibited by federal law.

To a large degree the welfare of the cable television industry is dependent on protective legislation. Many of the services considered the ex- 
Certainly, the cable industry considers itself hemmed in by various competitive encroachments; any natural monopoly analysis of CATV must consider these substitute forms of video delivery. The FCC finds that "the statistical evidence tends to support the proposition that the video product market should be defined broadly-to include (at least) broadcast television, cable, and VCR's." ${ }^{228}$ An analysis of CATV limited to that medium alone is inherently flawed by reliance on an illdefined product market.

clusive territory of cable television could, in fact, be supplied by other segments of the communications industry if they were allowed to by the regulatory authorities. The telephone industry, for instance, has virtually every television household in the country wired so that it could immediately provide various of the video and two-way services now promoted as significant sources of revenue for cable television.

Warburg Paribas Becker, Inc., Five Year Performance Survey of the Cable TV Industry (Dec. 1981), reprinted in Cal. Public Broadcasting Comm'n, The Impact of AB699: Community Service aNd Gable Rate DeREgulation apps. at 19 (1982) (footnote omitted). The same survey notes, "Video services include one-way data printout. The telephone industry's plant does not have the ability to transmit pictures." Id. at $19 \mathrm{n} .1$. The advent of fiber optics, however, may allow the telephone industry to discover a superior medium for transmitting pictures than co-axial cable. See infra note 244. Senator John Danforth, the chair of the Committee on Commerce, Science and Transportation, crafted an important cable policy statement in his recent letter of July 22, 1986 to FCC Chair Mark Fowler. In it he suggested the possibility that both telephone company competition to cable and the prohibition by federal law of the exclusive cable franchise itself may be issues ripe for discussion.

The Senate will have the opportunity to reexamine the decision of Congress to limit the provision of cable services by telephone companies ( 47 U.S.C. $\S 613$ ) in the context of reviewing restrictions now imposed upon the Regional Bell Operating Companies. Perhaps Congress may wish to reexamine, as well, its decision allowing franchising authorities to grant exclusive cable franchises (47 U.S.C. $§ 621$ ).

Letter from Sen. John C. Danforth to Mark S. Fowler, FCG Chairman (July 22, 1986) at n.17.

In a numerical projection concerning those technologies that are allowed to compete, Dr. Jane Henry estimates that non-CATV pay video transmission suppliers, excluding VCRs and nonsubscription television, will have 15.75 million subscribers in the United States by 1992. The largest CATV competitor will be MCTV (8.5 million subscribers), followed by DBS ( 4.0 million), SMATV ( 2.5 million), and LPTV (.75 million). See Henry, supra note 150, at 52-55.

228 J. Levy \& P. Pitsch, supra note 219 , at 31 . These three delivery systems mentioned are the only ones they tested for substitutability, hence their parenthetical use of "at least." 
Table 2

Intermedia Competition for the Video Entertainment Market*

\begin{tabular}{|c|c|c|c|c|c|c|c|}
\hline & CATV & SMATV & TVRO & DBS & MCTV & Broadcast TV & VCR \\
\hline $\begin{array}{l}\text { \# of Viewers } \\
\text { (households) }\end{array}$ & $34,000,000^{\mathrm{a}}$ & $600,000^{b}$ & $1,200,000^{\mathrm{c}}$ & n.a. & n.a. & $83,000,000^{d}$ & $25,000,000^{e}$ \\
\hline $\begin{array}{l}\text { Year begun } \\
\text { (approx.) }\end{array}$ & $1948^{f}$ & $1979-808$ & $1976^{h}$ & $1983^{\mathrm{i}}$ & $1984^{\mathbf{j}}$ & $1946^{k}$ & $1977^{1}$ \\
\hline $\begin{array}{l}\text { Capital cost } \\
\text { per viewing } \\
\text { household }\end{array}$ & $\begin{array}{c}\$ 900- \\
\$ 1,200^{\mathrm{m}}\end{array}$ & $\begin{array}{l}\$ 200- \\
\$ 400^{n}\end{array}$ & $\begin{array}{c}\$ 600- \\
\$ 1,500^{\circ}\end{array}$ & $<\$ 500 \mathrm{P}$ & $\$ 3009$ & trivial & $\$ 250^{r}$ \\
\hline $\begin{array}{l}\text { Henry's "Avg. } \\
\text { investment/ } \\
\text { subscriber"x }\end{array}$ & $\$ 765^{s}$ & $\$ 230^{5}$ & n.a. & $\$ 440^{s}$ & n.a. & n.a. & n.a. \\
\hline $\begin{array}{l}\text { Channel } \\
\text { capacity }\end{array}$ & $110^{2}$ & $108^{u}$ & $123^{y}$ & $16(\text { each })^{w}$ & $29^{x}$ & 82 & - \\
\hline $\begin{array}{l}\text { Nontrivial } \\
\text { sunk cost? }\end{array}$ & Yes & No & No & No & No & No & No \\
\hline
\end{tabular}

a Solomon, Cable TV is at a Crossroads-Trying to Figure Out What It Ought to Be, 17 NAT'L J., Nov. 2, 1985, at 2478, 2482.

b N.Y. Tìmes, Nov. 9, 1983, at D10, col. 1.

c TV Mushrooms in the Backyard, TiMe, Sept. 16, 1985, at 56 (number of existing satellite dishes in 1985).

${ }^{d}$ Revenues, Expenses, and Earnings-Television Stations: 1946-1980, 51 TeLEVISION AND Gable FACTBOOK 36 (Television Digest Inc.) (1983).

'Lachenbruch, VCR's From Gizmo to Household Word, 5 Channels of Comm. Nov./Dec. 1985 , at 74 (1986 Field Guide).

' Robinson, Introduction and General Background, in Deregulation of CABLE TELEVISION 1, 5 (P. MacAvoy ed. 1977); Letter from Sen. John C. Danforth to Mark S. Fowler, FCC chairman (July 22, 1986) ("The cable industry generally is recognized as having started in Mahanoy City [Pennsylvania] in 1948.").

B SMATV: The Medium That's Making Cable Nervous, Broadcasting, June 21, 1982, at 33.

h Barbieri, Backyard Dishes: DBS By Any Other Name, 5 Channess of Comm., Nov./Dec. 1985 , at 54.

i The Dish v. The Cable, NewsweEk, June 6,1983, at 75 (DBS broadcasts scheduled to begin in Oct., 1983).

$\mathrm{j}$ The Expanding World of Multichannel TV, BrondCASTING, Mar. 11, 1985, at 38 (a fourchannel system was introduced in Washington D.C. in December of 1984).

${ }^{k}$ Revenutes, Expenses and Earnings-Television Stations: 1946-1980, supra note d, at 6 (in 1946 , there were 10 U.S. television stations with total revenues of $\$ 500,000$ ).

${ }^{1}$ U.S. Bureav of the Census, Statistical ABstract of the United States: 1980, 835 (100th ed. 1981) (1977 was the first year for which figures for VCR's are given).

${ }^{m}$ Wall Street J., April 1, 1983, at 1, col. 6; Wines, Cable Companies Fall Victim to Overpromises, Competition for Viewers, 16 NAT'L J., Feb. 18, 1984, at 314, 315.

${ }^{n}$ Cherry Picking for Profit, Comm. Engineering \& Design, Dec. 1985, at 77, 80. Higher estimate from cost structure of Co-op City, a residential development in the Bronx and assuming a $50 \%$ penetration ratio, as reported in SMATV, supra note $\mathrm{g}$, at 38.

- Firms Urge Cable On, Cable Television Bus., 1985 Special Edition, at 10.

P Cable Marketing, Dec. 1985, at 30.20 . 
q Touche Ross \& Co., Financial and Economic Analysis of the Cable Television Permit Policy of the City and County of Denver 47 (Jan. 20,1984), citing Boyle, Multichannel to be Less Costly Than Cable: Microband, Multichannel News, Mar. 14, 1983, at 21.

${ }^{r}$ Lachenbruch, supra note e, at 74.

$s$ Taken from Henry, supra note $t$, at 19 . Henry's numbers specifically refer to "Average Transmission and Subscriber Investment Per Potential Subscriber" (Table 1.14, at 54).

'Wall Street J., Apr. 1, 1983, at 1, col. 6. According to the article, a "state of the art" cable system would have a 110 channel capacity.

"SMATV, supra note g, at 33 (example taken from proposed SMATV system for Co-Op City, a residential development in Bronx, New York).

' CommTek Pub. Co., Tuning in to Satellite TV, at v (1984) (promotional pamphlet). The pamphlet suggests that satellite dishes in general have a 123 channel capacity.

w Once Upon a Time in America?, Satellite World, Dec. 1985 at 16-17.

${ }^{x}$ Henry, The Economics of Pay-TV Media, in Video Media Competrtion, 19, 31 (E. Noam ed. 1985) (Henry refers to multichannel microwave distribution services [MMDS], which is another name for the transmission system known as Multichannel Television [MCTV].).

* As stated in the text, this table is included to facilitate the author's discussion of broadcasting systems that can serve as alternatives to cable. It is not meant to be a precise analysis of the market characteristics of industry competitors.

A listing of intermedia competitors to cable, such as that in table 2 , is enlightening in two regards. First, it illustrates that per subscriber capital costs for cable alternatives are competitive with cable; the competitive advantage of GATV due to the economic efficiency of spreading fixed capital charges over an entire market is shown to be suspect. ${ }^{229}$ Second, the important substitutes to CATV uniformly require relatively small nonsalvageable capital investments. For example, firms supply satellite television broadcasts by renting transmission services on orbiting satellites; hence, they have virtually no sunk investment. On the receiving end of satellite transmissions, viewers subscribe by purchasing satellite dishes that themselves may be relocated and are therefore salvageable. ${ }^{230}$ Because TVROs, SMATV, DBS, VGRs, broadcast television, and MCTV do not require suppliers to make large and nonsalvageable investments in order to enter the market, the video entertainment market is plausibly contestable. Hence, the demonstration that CATV systems are spatially separated is of limited value in drawing conclusions on the competitiveness of a correctly defined mar-

229 The figures appearing in table 2 are not intended to be exact projections of actual costs, which, of course, vary from market to market. They are, however, estimates taken from published or industry expert sources. They should serve as highly plausible guesstimates no less reliable than the projections made by municipally retained analysts to support the claim that high fixed costs make direct cable competition impractical and uneconomical. Hence, the inevitable imprecision of cost estimates is properly a greater cause of concern for those who argue that such forecasts create a case for legal monopoly. At a minimum, it is not persuasive to bolster a natural monopoly argument with a set of suspect numbers, and then to dismiss cross-competition due to the problems inherent in relying on other imperfect numbers.

230 Capital mobility is epitomized by the satellite dishes now on the market, which may be attached to recreational vehicles. 
ket in which CATV competes.

\section{The Obvious and Hidden Costs of Political Rent-Creation}

Even on its own terms, the argument for a monopoly franchise is today a curiosity in the cable market, given current federal policy. In the traditional view of natural monopoly regulation, a monopoly franchise serves solely to facilitate a regulatory scheme. An argument exists for regulation without a monopoly franchise, that is, regulation of a de facto monopoly, but there has never been a proconsumer argument monopoly franchise without price regulation. ${ }^{231}$ Recently, a peculiar regulatory arrangement has evolved: because Congress has legislated a phasing out of local control over cable television prices, the argument for monopoly franchising dissolves into a blank check for monopoly power. ${ }^{232}$ It is suspect to argue against the efficacy of market forces in regulating cable prices and services in the consumer's interest when the alternative is legal monopoly with no price regulation. The assertion that unregulated private monopoly without the possibility of competitive entry is better for consumers than unregulated private monopoly with the possibility of competitive entry is simply not credible.

A policy of exclusive franchising without price regulation may effectively limit supply but does not limit monopoly pricing. Furthermore, the dead weight losses associated with monopolistic output restrictions in standard monopoly theory are not the only welfare losses incurred through the franchising process. The substitution of political selection for consumer selection inevitably introduces economic inefficiencies because decisions are made by individuals who do not bear the associated costs. Hence, costs induced by franchising must be added to the dead weight costs traditionally associated with monopoly.

To quantify the various costs of political franchising is treacherous, given the many necessary assumptions that must be employed about a multitude of franchise variations. To assist in putting the franchising discussion in appropriate perspective, however, it is helpful to advance an estimate of the costs of local licensing of cable television.

Costs of public access and local origination programming: These costs

231 The regulation of prices has always been advanced by the advocates of monopoly franchises as the consumer's protection after market competition is foreclosed. "Local governments typically protect their citizens from cable's monopoly power by regulating rates for basic subscriber services, insuring access for users on a nondiscriminatory basis, and setting minimum service standards." Miller \& Beals, Regulating Cable Television, 57 WASH. L. REV. 85, 96 (1981).

${ }^{232}$ See supra note 57. 
include payments for the establishment of production facilities, ${ }^{239}$ excess channel capacity, and direct grants to community organizations. They have been estimated in the typical cable franchise case to equal $\$ 4.81$ per subscriber per month by Ernst \& Whinney, and $\$ 6.00$ per subscriber per month in the Denver, Colorado franchise, specifically, by the Cable Television Information Center. ${ }^{234}$ Since these studies projected far different average monthly revenues per subscriber $(\$ 22.45$ versus $\$ 37.50$, respectively), these estimates range from $22 \%$ to $16 \%$, respectively, of total cable revenue. ${ }^{2 s 5}$ Franchise fees, a direct and explicit cost of the franchising process, are not included in these estimates.

Costs of delays in awarding a franchise: Local regulators can impose high penalties on consumers by their delays in choosing a franchisee. A 1982 Consumers' Research article noted one such instance. While the chairman of the County Board of Supervisors in franchised Fairfax, Virginia labeled neighboring Prince William County's free entry policy a disaster, the magazine noted that "Prince William County citizens, however, currently have cable services, as most Fairfax County residents do not." 238

What are the social costs of political delay? At a minimum, the benefits of cable television reach the public after a delay of several years, because cities typically devote between two and ten years to the process of deciding upon a franchisee. ${ }^{237}$ Consumer welfare analysis of

2ss In the South Central Los Angeles franchise competition, the winning bidder promised to help program 21 public access and 8 government access channels by investing in 25 neighborhood production facilities that were to receive video production equipment taking three and one-half pages to list. See Supplemental Report: Evaluation and Recommendation of Highest Responsible Bidder for the Cable Television Franchise in South Central Area of Los Angeles, attachment C at 11-15 (Sept. 17, 1981) (Los Angeles Dep't of Transp., Reference No. C.F. 78-5672, S1, S2).

2si See Ernst \& Whinney, supra note 100, at 3; Touche Ross \& Co., supra note 74 , at 41 .

${ }^{285}$ See Ernst \& Whinney, supra note 100, at 3; Touche Ross \& Co., supra note 74 , at 41 .

${ }^{288}$ Cable Could Compete, Consumers' Res., Oct. 1982, at 22, 23. While studies endorsing monopoly franchising often point to litigation problems occasionally experienced in multiple franchise jurisdictions, no consideration is given to delay problems inherent in awarding exclusive franchises. Moreover, the easily available solution to either set of problems is to dispense with franchises altogether by simply establishing an open entry policy. Under such a policy, the local government sets fees and rules for public uses that apply equally to all entrants, and the political delay is reduced to virtually zero. It is also interesting to note that such studies find that competition spurs cable construction, thus producing a double timing advantage to open entry policies.

${ }^{237}$ For example, the Dallas franchisee secured approval of the city council and completed construction of $50 \%$ of the city's cable system within three years. In contrast, the process to select the franchisee for the East San Fernando Valley area of Los Angeles extended over more than five years, amid charges that city council members were intentionally delaying the selection in order to collect campaign contributions from the 
the costs of franchising must take into account the time preferences of consumers. The delay caused by the franchising process cannot be justified unless the additional benefits achieved through franchising outweigh the social costs to consumers of foregoing cable television services during the selection process. ${ }^{298}$

Costs of political lobbying: It has been customary for large, nationally integrated multiple system operators to establish locally-based subsidiaries for each new franchise contest, and to transfer $20 \%$ (or more) of the subsidiary stock to politically influential local figures. ${ }^{239}$ In addition to assigning away at least $20 \%$ of anticipated profits, franchise bidders often undertake large advertising, public relations, and lobbying campaigns. ${ }^{240}$ These campaigns entail significant expenses: typically these costs (inclusive of stock awards) may amount to between $20 \%$ and $33 \%$ of total profits. Estimating gross margin to be $13.68 \%,{ }^{241}$ lobbying costs are projected to total between $\$ 0.62$ and $\$ 1.82$ per subscriber per month.

cable companies vying for the franchise. See Getlin, Council Postpones Cable TV Decision, L.A. Times, Feb. 16, 1983, at II-1, col. 4; Getlin, TV Cable Franchise Fight in Valley is Longest-Running, L.A. Times, Jan. 17, 1983, at II-1, col. 4. Philadelphia has had no less than four franchising processes since 1966 and still has not selected a franchisee. See Cooke \& Sutton, Goode Scraps Cable-TV Applications to Start Over, Phila. Inquirer, Jan. 26, 1984, at 1-A, col. 1. Awareness of the potential for delays of this sort has led those city councils particularly anxious for cable to let competition get the job done.

${ }^{238}$ Suppose, by way of example, that we attribute a three-year delay to the franchising authority, a fair estimate of the average time delay, in that two years appears to be the lower bound and many franchising battles have lasted far longer. Discounting at a real interest rate of $4 \%$ (below recent interest rates, but reasonable historically) means that whatever benefits cable brings to consumers will, measured quantitatively, be worth only 88.9 cents on the dollar. The $11.1 \%$ loss is due to the time preference of consumers-people choose to have good things sooner rather than later. Perhaps a clearer way to view this loss is to note that the government franchising agreement, to justify its benefits to consumers, would have to deliver a package that on net (i.e., after the various costs of such regulation were subtracted) had a value to consumers $12.5 \%$ greater than the unfranchised alternative. This political-haggling discount suggests that slender or subtle advantages not easily demonstrable in existing data make a very weak case for franchise monopoly.

2as See supra note 86.

240 See supra note 87. See also KINLEY, Simpson \& Associates, WesteRN Franchise ReVIEw, Oct. 1985, at 6 (describing the proposed assignment of $45 \%$ of a cable company's equity to the cable franchising authority).

241 This figure is based on the average gross margin of all 34 publicly held domestic cable operators, as given in 1982 industry data compiled by Communications Equity Associates, in the Cable TV Financial Databook, June 1984, at 90. 
Table 3

Politically Imposed Costs of Franchise Monopoly*

\begin{tabular}{|c|c|c|c|c|c|}
\hline & $\begin{array}{c}\text { (I) } \\
\text { Uneconomic } \\
\text { Investment }\end{array}$ & $\begin{array}{c}\text { (II) } \\
\text { Delaye }\end{array}$ & $\underset{\text { Lobbying }}{\text { (III) }}$ & $\begin{array}{c}(I V) \\
\text { Franchise } \\
\text { Fees }^{i}\end{array}$ & $\begin{array}{l}\text { Total } \\
\text { Costs }\end{array}$ \\
\hline $\begin{array}{l}\text { Low Estimate } \\
\text { (percent of low } \\
\text { revenue estimate } \\
{[25.83]^{2}}\end{array}$ & $\begin{array}{l}4.81^{\mathrm{c}} \\
(19 \%)\end{array}$ & $\begin{array}{c}.97 \\
\text { (2 years) }\end{array}$ & $\begin{array}{c}.71 \mathrm{~g} \\
\text { (20\% of } \\
\text { gross } \\
\text { margin) }\end{array}$ & $\begin{array}{l}1.29 \\
(5 \%)\end{array}$ & $\begin{array}{c}7.78 \\
(30 \%)\end{array}$ \\
\hline $\begin{array}{l}\text { High } \\
\text { Estimate } \\
\text { (percent of high } \\
\text { revenue estimate } \\
[37.50]]^{\mathrm{b}}\end{array}$ & $\begin{array}{l}6.00^{d} \\
(16 \%)\end{array}$ & $\begin{array}{c}2.72 \\
\text { (4 years) }\end{array}$ & $\begin{array}{c}1.71^{\mathrm{h}} \\
(33 \% \text { of } \\
\text { gross } \\
\text { margin) }\end{array}$ & $\begin{array}{l}1.88 \\
(5 \%)\end{array}$ & $\begin{array}{l}12.31 \\
(33 \%)\end{array}$ \\
\hline $\begin{array}{l}\text { Mid-Point } \\
\text { Estimate }\end{array}$ & $\begin{array}{c}5.41 \\
(17 \%)\end{array}$ & $\begin{array}{c}1.84 \\
(5.8 \%)\end{array}$ & $\begin{array}{c}1.21 \\
(3.8 \%)\end{array}$ & $\begin{array}{l}1.58 \\
(5 \%)\end{array}$ & $\begin{array}{l}10.04 \\
(32 \%)\end{array}$ \\
\hline
\end{tabular}

(percent of mean

revenue estimate

[31.67])

${ }^{a}$ Ernst \& Whinney, The Cost of Cable Television Regulatory \& Franchise Requirements: A Preliminary Analysis 47 (Apr. 1982) (unpublished study prepared for the National Cable Television Association).

${ }^{b}$ Touche Ross \& Co., Financial and Economic Analysis of the Cable Television Permit Policy of the Gity and County of Denver 41 (Jan. 20,1984) (unpublished study). This survey produced the high estimate. Other estimates are consistent with these numbers. National Economic Research Associates projected that a typical 10,000 home urban franchise would require an average $\$ 6.09 / \mathrm{mo}$./sub. in regulatory costs and franchise iees. (A projection for a 300,000 home urban franchise fell to $\$ 4.29 / \mathrm{mo}$./sub., but such size franchises are rare. National Economic Research Associates, Costs of Cable Television Franchise Requirements 14, app. 1-2 (Feb. 14, 1984) (unpublished study prepared for the National Cable Television Associate)). In Sacramento, a 330,000 home franchise area, regulatory costs have been estimated at $\$ 7.48 / \mathrm{mo}$./sub. using evidence in Opening Brief for Plaintiff at 8, Pacific West Cable Co. v. City and County of Sacramento, 798 F.2d 353 (9th Cir. 1986); Testimony of Jay Smith at exhibit 2 in id.

c Ernst \& Whinney, supra note a, at 47.

¿Touche Ross \& Co., supra note b, at 41.

c "Delay" figures are based on an assumed real discount rate of $4 \%$ and a linear demand curve with a slope equal to -1 . We further assume that the cable firm sets the price where elasticity of demand equals 1 . (This is where the profit-maximizing firm would, in fact, set price if $M C=0$.) The delay cost represents the difference between the average monthly consumer surplus (which, given our assumed demand curve, equals one half the average monthly revenue) and the discounted value of this surplus computed by dividing the average monthly consumer surplus by $(1.04)^{n}$ where $n$ is the number of years over which the surplus is being discounted, in this case the number of years consumers were forced to defer their enjoyment of cable television while waiting for the franchise process to run its course. Here we ignore any producer losses emanating from franchise delay.

$\mathrm{f}$ The figures in this column are derived from determining the gross profit of a cable company (which, for the purposes of this table is assumed to be $13.68 \%$ of total revenues, the national average for the 34 publicly held U.S. cable companies operating in 1983, see Community Equity Associates, The Cable TV Financial Databook 90 (June 1984), and then computing a dollar value representing the percentage of gross profits devoted to securing the franchise through advertising, promotion, campaign contributions, etc. 
8 The $20 \%$ figure is a low estimate of total lobbying cost, representing the typical percentage of a cable company's stock granted without equity contributions to local community organizations. See supra note 75.

h Although a cable company bidding for a franchise in Santa Cruz, California recently proposed that $45 \%$ of its equity be given to the city and county franchising authority, see KINLEY, SIMPson \& Associates, Western Franchise Review, Oct. 1985, at 6, a more realistic high "guesstimate" would be $33 \%$.

i The Cable Communications Policy Act of 1984 sets a 5\% ceiling on franchise fees. See 47 U.S.C. $\S 542$ (b) (Supp. III 1985).

- As stated in the text, this table is not presented as a definitive measurement of the political costs of cable franchising but is offered for illustrative purposes in our discussion of the net effects of government franchising. All figures in table are in dollars per subscriber per month, unless otherwise noted.

Table 3 presents the estimated political costs of franchising ${ }^{242}$ and demonstrates that they are significant. ${ }^{243}$ Given reasonable inferences, it is likely that costs imposed on cable consumers and suppliers approximate one-third of total revenue, or more than twice the amount of pretax profit.

Finally, consumers have a clear interest in flexibility should a new entrepreneur or a new technology appear capable of providing improved service. In an industry as dynamic as modern telecommunications, any practice that binds consumers to a long-term exclusive dealing arrangement, as does franchising, has the potential to impose significant disadvantages. ${ }^{244}$ The idealized case for monopoly franchising, even if it could be complemented by a proven record of demonstrable consumer benefits, must confront the costliness of the lack of choice in contracting. Regulatory boards inevitably become wedded to the firms and technologies they regulate and are likely to attempt to thwart the very innovation that would hurt the natural or legal monopolists that the boards are charged to regulate. Judge Posner has identified

242 These cost estimates are not intended to be precise measures of politically imposed costs, but simply reasonable calculations pointing to the order of magnitude involved in costly cable regulation. Such projections under uncertainty must be made in any forthright assessment of the net benefits of franchise monopoly.

24s Both economic costs from output restriction, and X-inefficiency, or dynamic costs incurred when entrepreneurial innovation is denied consumers of franchise monopoly, are excluded from this analysis.

244 As one study notes:

Electronics and information technology have evolved enormously over the last three decades. There is every indication that this evolution will continue for at least one or two more decades. Neither cable television nor its competitors are yet fully developed. At best, we have only a sketchy and limited view of the structure of the communications future. If we look back only a decade to the Sloan Commission and the Rostow reports, we see no mention of multichannel MDS as a competitor to cable. Neither report discusses fibre optics-naturally enough, since practical fibre optics communications systems had yet to be invented.

Shooshan, Jackson, \& Kahn, supra note 189 , at $42-43$ (footnotes omitted). 
this reality of regulation as the central issue in the analysis of monopoly franchising:

It is quite true that at any point the case for regulation is stronger in some regulated industries than in others, depending on the degree to which conditions of natural monopoly are actually present. But natural monopoly conditions are quite likely to be transient. . . . Communications is a contemporary example of an industry undergoing rapid technological changes that are apparently opening up a host of new competitive opportunities. In general, the tempo of change in the economy seems to be increasing. The most pernicious feature of regulation would appear to be precisely its impact on change-its tendency to retard the growth of competition that would erode the power of regulated monopolists. To embrace regulation because an industry is today a natural monopoly and seems likely to remain so is to gamble dangerously with the future. To impose regulation on the basis of a prophecy that the industry will remain monopolistic forever may be to make the prophecy self-fulfilling. ${ }^{245}$

The record of economists and regulators in abstractly identifying candidates for natural monopoly regulation is concededly poor. As recently as 1978, a leading analyst of the telecommunications industry could calmly state, "The most difficult cases for deregulation come in the long distance telephone and terminal equipment markets, with their blends of monopoly and competition. Here, it may not be feasible for government regulation simply to disappear. In any event, it is unlikely that it will disappear soon."246 The subsequent development of competition in the long-distance telephone market looms as an ominous precedent to those who argue that the operator of a cable television franchise enjoys a natural monopoly. ${ }^{247}$ The cable industry, beset by competitive pressures in the short and the long run, demonstrates nervousness uncharacteristic of an entrenched natural monopolist:

[F]ear persists about the long-term competition [that small backyard satellite dishes] and other technologies pose for

245 Posner, supra note 63, at 636.

248 Besen, Deregulating Telecommunications-Sorting Out Mixed Signals, REGulation, Mar./Apr. 1978, at 30, 36.

247 As Bruce Owen, a leading telecommunications analyst, has written: "Ironically, the econometric evidence in favor of the idea that there was a natural monopoly in the long distance telephone business, a business now generally accepted to be at least workably competitive, was probably stronger than the evidence suggesting that cable is a natural monopoly." Owen, supra note 71 , at 5 . 
cable. Cable operators worry about the "trolley car syndrome, the fear that the thousands of miles of cable that have been strung in the last 30 years might go the way of the thousands of miles of trolley car tracks that once crisscrossed the country if some new technology comes along that makes cable obsolete."248

\section{ConClusion}

In this era of federal deregulation, the arguable efficiency rationale for franchising has vanished because regulators can no longer suppress rates in order to prompt the expansion of output. In its standard formulation, the problem posed by monopoly is that, where ready substitutes are unavailable, a firm can maximize profit by restricting output to below the competitive level, thereby driving prices above costs. A cable firm, for instance, can restrict output by lowering penetration. The inefficiency of monopoly is that the marginal consumers who are driven from the market by the monopolistic restriction of supply are willing to pay the opportunity cost of additional production, but are foreclosed from doing so by the monopolist's quest for excess returns.

There are two predictable consequences of a monopolistic restriction. ${ }^{249}$ First, the monopolist makes $X$ more from those customers $A$ who are willing to consume at either competitive or monopoly prices. These consumers must pay prices that are higher by precisely the amount that the monopolist gains. These payments constitute a pure transfer, so far as the analysis goes, from $A$ consumers to the monopolist. Because the dollar gains of one party are exactly offset by the dollar losses of another, no positive economic judgments are obvious. Second, the efficiency concern with monopoly centers on what happens to marginal customers $B$ when the monopolist establishes a price above costs $P_{\text {mono }}$. The difference between what those customers are willing to pay for incremental units of output, minus the opportunity cost of producing those units (demand - marginal cost) is the consumers' surplus $Y$ lost by the monopolistic restriction. These losses are not offset by corresponding gains to any party and are therefore labeled deadweight loss in economic analysis; they form the basis of the positive or "scientific" argument against monopoly in the economics literature. The presence of such losses demonstrates that monopoly, while generating both

248 Solomon, supra note 216, at 2482 (quoting Thomas P. Southwick, editor of Multichannel News).

240 This graphical analysis may illuminate the explanation, although the text may be read on its own by simply ignoring the bold letter references. 
gains for the monopolist and losses for consumers, creates more of the latter. Hence, even a neutral analyst may conclude that monopoly yields a net loss in social welfare and thus may condemn it as economically inefficient.

In the context of rate deregulation, this analysis clarifies the inquiry into the economic effects of cable franchising. If rates were regulated, an economic debate on the relative costs and benefits of regulated franchises would be in order to determine whether local regulation lowers prices enough so as to expand output sufficiently and thereby justify the costs to society of imposing such regulation. This would rest on a complex, empirical inquiry. Now, however, the cable market faces no such regulatory trade-off. With unregulated pricing for basic and premium programming, a monopoly franchise confers protection from competition without guaranteeing any offsetting constraint on rates. The "deregulated franchise monopoly" emerges as a curious creature of public policy, in that the most that a perfectly informed and properly motivated city council could accomplish would be to transfer monopoly profits from supplier to city government. If a local government were

\section{Price/Cost (\$)}

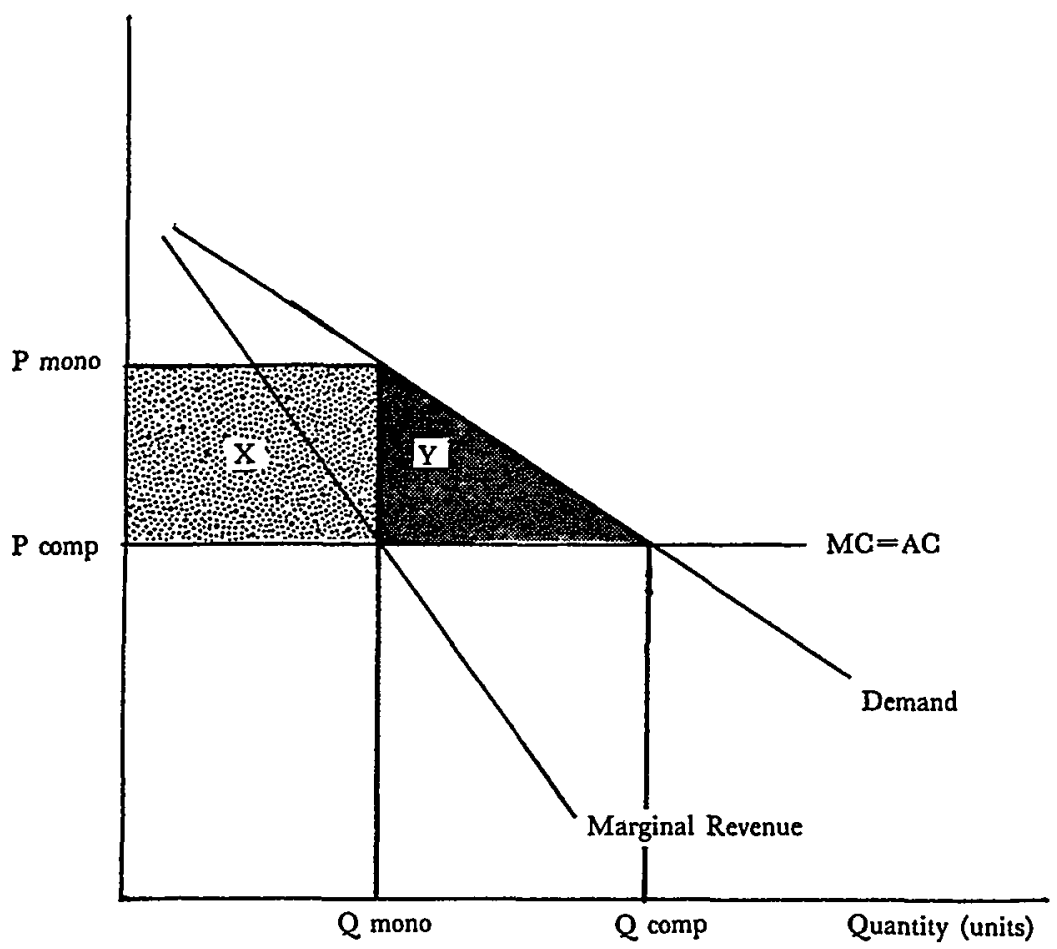


simply to accept the highest monetary bid for its cable franchise, ${ }^{250}$ it would be engaged only in a transfer of monopoly rents. This transfer produces no economic efficiency, and, in a real world setting, must actually introduce specific sources of inefficiency:

(1) The cable firm and cable products selected by the local government will differ from what consumers would select in a free competition for their patronage. Government's knowledge of what consumers prefer is inherently bounded; much information about consumer preferences is incommunicable outside the context of market rivalry. Moreover, political selections are dramatically biased toward the desires of interest groups who aim to supply, or otherwise profit from, the franchise. Such interest groups realize no positive net reward in faithfully representing consumer interests.

(2) The franchising process is expensive. It delays delivery of cable services to consumers. It promotes costly political competitions in which lobbying efforts consume significant real resources.

(3) The franchiser may not accept cash payments from the franchisee in excess of $5 \%$ of gross receipts. ${ }^{251}$ As a result, the winning auction bid must be paid in cash and in concessions from the cable operator. Such concessions often result in inefficient allocations of resources. Excess channel and programming capacity, extensive and underutilized local origination facilities, and an imaginative array of community improvement payments all represent investments that cost suppliers more to provide than they are worth to consumers.

(4) Assuming, arguendo, that natural monopoly cost conditions exist, legal monopoly adds an additional entry barrier to the economic barriers already present, thereby increasing the likelihood, magnitude, and duration of monopolistic output restrictions. ${ }^{232}$

All four of these sources of inefficiency are significant ${ }^{263}$ and provide a straightforward economic calculus. Because the argument for monopoly franchises must now be grounded solely on redistributional advantages and because monopoly predictably generates considerable welfare losses, a positive analysis must reject the monopoly franchise

${ }^{250}$ Highest monetary bid means highest in terms of present value.

281 The Cable Communications Policy Act of 1984 sets a 5\% ceiling on franchise fees. See supra note 85 . If cities truly believed cable firms to be homogeneous natural monopolists, they would have no reason to franchise. They could collect by simply imposing a tax of $5 \%$ of gross revenues on all entrants. A natural monopoly would quickly be established by market competition and the maximum legal transfer to the government would still be extracted.

252 Judge Posner clearly articulated this aspect of the inefficiency caused by franchising. See supra note 65 and accompanying text.

${ }^{253}$ See table 3, supra p. 1402. 
for the cable television industry. On efficiency grounds, the cable television monopoly franchise is a net loss to society.

The argument currently made by proponents of monopoly franchising reveals the disadvantages of such franchising. The argument asserts that selection of the inevitable cable monopolist by a local government will produce a better cable system than selection by the open marketplace. Supporters of this argument claim that "[i]n the absence of carefully defined franchise requirements and a competitive franchising process, it is unlikely that cable systems will be used to their fullest potential,"254 and that "[ $t]$ he public's right to universal service and a diversity of opinion is best served by the traditional franchise system."25s

It is essential to see that advocating exclusive cable franchising on the ground that politically selected and legally protected monopolists will be better quality providers is not a natural monopoly argument, but a plea for monopoly creation based on the premise that a politically franchised choice will be superior to a competitive, consumer choice. In fact, this argument clearly contradicts the pro forma natural monopoly case that sees the issue of product quality as an insignificant choice between identical firms. Where suppliers do offer importantly different packages, the political regulation of a natural monopoly does not follow from the demonstration of natural monopoly cost conditions, because there exists no reliable political mechanism for determining which natural monopolist is best in economic terms.

For cities to argue, then, that their franchisees are better cable operators than those which might survive a competition for the market is to contradict the assertion of natural monopoly. The franchising of vast 120 -channel systems with two-way interactive capabilities, along with massive commitments to subsidize all manner of politically profitable projects and programming services for which little or no consumer demand exists, maxy indeed be made possible by a rigorous competition for the monopoly that the exclusive franchise fosters. This, however, is not an innocent proconsumer solution of the natural monopoly problem, but the overruling of consumer selection by political fiat.

2s4 Pols, Why Cable-TV Monopolies Make Sense, L.A. Times, Jan. 3, 1983, at II5 , col. 2 (view of Cynthia Pols, cable analyst for the National League of Cities).

${ }^{285}$ Finneran, Local Monopolies Serve the Public Best, N.Y. Times, Nov. 17, 1985 , at F-2, cols. 3, 6 (view of William B. Finneran, chairman of New York Commission on Cable Television). 
